\title{
Biosynthesis of zinc oxide nanoparticles using
} Albizia lebbeck stem bark, and evaluation of its antimicrobial, antioxidant, and cytotoxic activities on human breast cancer cell lines

This article was published in the following Dove Press journal:

International Journal of Nanomedicine

\section{Huzaifa Umar ${ }^{1-3}$ \\ Doga Kavaz ${ }^{1-3}$ \\ Nahit Rizaner ${ }^{1-3}$}

'Department of Bioengineering, Institute of Graduate Studies and Research, Cyprus International University, Mersin, Turkey; ${ }^{2}$ Biotechnology Research Center. Cyprus International University, Mersin, Turkey; ${ }^{3}$ Bioengineering Department, Cyprus International University, Mersin, Turkey
Correspondence: Huzaifa Umar Department of Bioengineering, Institute of Graduate Studies and Research, Cyprus International University, 98258 Northern Cyprus via Mersin 10, Turkey Tel +90542888 8419

Email humar@ciu.edu.tr

\begin{abstract}
Background: Biocompatibility and stability of zinc oxide nanoparticles ( $\mathrm{ZnO} \mathrm{NPs}$ ) synthesized using plants is an interesting research area of study in nanotechnology, due to its wide applications in biomedical, industrial, cell imaging, and biosensor fields. The present study reports the novel green synthesis of stable $\mathrm{ZnO} N$ Ps using various concentrations of zinc nitrate $(0.01 \mathrm{M}, 0.05 \mathrm{M}$, $0.1 \mathrm{M})$ and Albizia lebbeck stem bark extracts as an efficient chelating agent. Antimicrobial, antioxidant, cytotoxic, and antiproliferative activities of the synthesized NPs on human breast cancer cell lines were evaluated using different assays.
\end{abstract}

Methods: Characterization of the synthesized $\mathrm{ZnO}$ NPs were carried out using various spectroscopic and microscopic techniques. Antimicrobial activity evaluation using disc diffusion method, antioxidant activity using hydrogen peroxide $\left(\mathrm{H}_{2} \mathrm{O}_{2}\right)$ free radical scavenging assay and cytotoxic activity on MDA-MB 231 and MCF-7 using tryphan blue dye exclusion and MTT assay. Results: The UV-vis spectroscopy result revealed an absorption peak in the range of $370 \mathrm{~nm}$. The involvements of $A$. lebbeck bioactive compounds in the stabilization of the ZnO NPs were confirmed by X-ray diffraction and Fourier transform infrared analysis. Zeta sizer studies showed an average size of $66.25 \mathrm{~nm}$ with a polydisparity index of 0.262 . Scanning electron microscopy (SEM) and energy-dispersive X-ray spectroscopy (EDX) analyses results revealed irregular spherical morphology and the presence of primarily $\mathrm{Zn}, \mathrm{C}, \mathrm{O}, \mathrm{Na}, \mathrm{P}$, and $\mathrm{K}$, respectively. The biosynthesized ZnO NPs revealed strong antimicrobial potentials against various gram-negative and gram-positive bacterial pathogens. Antioxidant activities carried out using $\mathrm{H}_{2} \mathrm{O}_{2}$ free radical scavenging assay revealed higher IC50 values of $48.5,48.7$, and $60.2 \mu \mathrm{g} / \mathrm{mL}$ for $0.1 \mathrm{M}, 0.05 \mathrm{M}$, and $0.01 \mathrm{M} \mathrm{ZnO} \mathrm{NPs}$, respectively. Moreover, the biosynthesized $\mathrm{ZnO}$ NPs showed significant cytotoxic effects on MDA-MB 231 and MCF- 7 breast cancer cell lines $(P<0.001, \mathrm{n} \geq 3)$ in a concentration-dependent manner.

Conclusion: Overall, various concentrations of $\mathrm{ZnO}$ NPs were synthesized through a stable, simple, and eco-friendly green route via the use of $A$. lebbeck stem bark extract. The biosynthesized $\mathrm{ZnO}$ NPs showed strong antimicrobial, antioxidant and cytotoxic activity against strongly and weakly metastatic breast cancer cell lines.

Keywords: biosynthesis, antimicrobial, antioxidant, cytotoxic, biocompatibility

\section{Introduction}

Nanotechnology is a rapidly growing area of studies that utilizes biosynthetic and environmental-friendly technology for the purpose of synthesis of zinc oxide nanoparticles (ZnO NPs), which are known to be nontoxic, chemically stable, biocompatible, and could be used as drug carriers, ${ }^{1}$ cell imaging agents, ${ }^{2}$ anticancer agents, ${ }^{3}$ antimicrobials, ${ }^{4}$ biosensors, ${ }^{5}$ antidiabetics, ${ }^{6}$ and cosmetics, ${ }^{7}$ because of their novel physicochemical 
properties. Biocompatibility of zinc has been attributed to its presence in human system as the second most common and essential trace elements after iron with diverse role in body metabolic activities, and it is the fourth most commonly consumed metals worldwide. ${ }^{8}$ The physical and chemical methods that are used for the synthesis of metal oxide NPs are expensive and toxic, and antagonistic chemicals are used as a stabilizing agent. ${ }^{9}$ Metals oxide NPs modifications could be achieved by substitution with specific atoms, which then enhance optical, mechanical, and electrical properties of materials by changing their chemical surface properties. ${ }^{10} \mathrm{ZnO}$ NPs have recently gained special attention due to their hexagonal phase, n-type semiconductor, and wurzite structure. ${ }^{11}$ Green biosynthesis of $\mathrm{ZnO}$ NPs is simple, viable, and cost-effective and provides high yield with novel physical appearance, compared with other NPs such as silver, gold, titanium, and nickel. ${ }^{12}$

Recent studies have demonstrated the antibacterial potential of ZnO NPs through disruption of the cell membrane integrity, against extended-spectrum beta-lactamase-producing bacteria Klebsiella pneumonia and Escherichia coli. ${ }^{13}$ It has been recommended that $\mathrm{ZnO}$ NPs could retard E. coli growth through disorganizing the bacterial cell membrane, which increases permeability of the NPs through the membrane, leading to its accumulation in the cytoplasm and cell disruption. ${ }^{14}$ However, some microorganisms appear to show strong resistance against $\mathrm{ZnO}$, but $\mathrm{ZnO}$ NPs showed strong antimicrobial activities on certain pathogenic bacteria such as Salmonella enteritidis, Listeria monocytogenes, Bacillus subtilis, Staphylococcus aureus, and E. coli. ${ }^{15-17}$ Medicinal plants are known to possess vitamins, terpenoids, and phenolic compounds that have antioxidant potentials, ${ }^{18}$ but literature showed that synthesized NPs using medicinal plants as dispersing agents display more antioxidant activity in vitro. ${ }^{19}$ Suresh et al reported $\mathrm{ZnO}$ NPs synthesized using Cassia fistula to exhibit significant antioxidant activities through scavenging of 1,1-diphenyl-2-picrylhydrazil (DPPH) radicals. ${ }^{20}$ Investigations on the cytotoxic activity of $\mathrm{ZnO}$ NPs demonstrate cytotoxic effect against cancerous cells and normal cells including lung epithelial cells ${ }^{21}$ and human lens epithelial cells. ${ }^{22}$ Green synthesis of ZnO NPs using various medicinal plants including Costus pictus D. Don, ${ }^{23}$ Pongamia pinnata, ${ }^{24}$ Vitex negundo, ${ }^{25}$ and Cassia auriculata $^{26}$ has been reported to exhibit cytotoxic activity.

Albizia lebbeck is a tropical species that belongs to Albizia genus, mostly growing to an average height of $24 \mathrm{~m}$, trunk width of $50 \mathrm{~cm}$, and seed pods that contain 6-12 seeds. The plant is widely distributed in Australia, Asia, Africa, and Southern America. ${ }^{27}$ The seeds of the plant demonstrate antitumor, antifungal, and antibacterial activities against HepG2 hepatoma cells, fungi Rhizoctonia solani, and E. coli. ${ }^{28}$ The leaves of the plant contain phytochemicals such as flavonoids, tannins, alkaloids, triterpenoid saponins, and cardiac glycosides that have therapeutic value. ${ }^{29}$

In the present study, cost-effective green synthesis of $\mathrm{ZnO}$ NPs using $A$. lebbeck aqueous extract as a capping agent and their characterization using various spectroscopic techniques are reported. The antibacterial activity of the synthesized NPs was studied against five pathogenic microorganisms: two gram-positive (Bacillus cereus and S. aureus) and three gram-negative (E. coli, K. pneumoniae, and Salmonella typhi). The in vitro free radical scavenging activity of $\mathrm{ZnO}$ NPs was assessed by hydrogen peroxide $\left(\mathrm{H}_{2} \mathrm{O}_{2}\right)$ free radical scavenging assay. Furthermore, we investigated antiproliferative and cytotoxic activities of the NPs against human breast cancer lines MDA-MB 231 and MCF-7. The results are reported and images are presented.

\section{Materials and methods Preparation of A. lebbeck extract}

Fresh stem barks of $A$. lebbeck were collected from Gaya Local Government Area, Kano State (Nigeria: $11^{\circ} 52^{\prime} 5^{\prime \prime} \mathrm{N}$ and $9^{\circ} 0^{\prime} 40^{\prime \prime} \mathrm{E}$ ) and authenticated by a botanist at the herbarium of the Department of Plant Biology, Bayero University Kano, Nigeria. The specimen was given a voucher number BUKHAN187 and was deposited at the herbarium of the institute. The barks were washed properly with deionized water, shade dried, and then pulverized into coarse powder using mortar and pestle. A. lebbeck aqueous extract was prepared by slight modifications of the method described by Suresh et al. ${ }^{20}$ Briefly, the extraction was performed using water as a solvent in which $20 \mathrm{~g}$ of the coarse powder was soaked in $100 \mathrm{~mL}$ deionized water in a conical flask and was heated in a water bath under constant shaking at $45^{\circ} \mathrm{C}$ for 24 hours. The extract was then filtered using Whatman No 1 filter paper and the filtrate was stored at $4^{\circ} \mathrm{C}$ until used.

\section{Synthesis of $\mathrm{ZnO}$ nanoparticles}

$\mathrm{ZnO}$ NPs were prepared successfully using A. lebbeck aqueous extract by the method of Elham Zare et al with slight modifications. ${ }^{30}$ The ZnO NPs were synthesized using $0.01 \mathrm{M}$, $0.05 \mathrm{M}$, and $0.1 \mathrm{M} \mathrm{Zn}\left(\mathrm{NO}_{3}\right)_{2} \cdot 6 \mathrm{H}_{2} \mathrm{O}$ solution in $90 \mathrm{~mL}$ distilled water; then, $10 \mathrm{~mL}$ of the prepared $A$. lebbeck extract was added dropwise into the zinc nitrate solutions under constant stirring at $60^{\circ} \mathrm{C}$ for 5 hours to achieve a complex formation, and $\mathrm{NaOH}(5 \mathrm{M})$ was added to the solution during stirring process to adjust the $\mathrm{pH}$. Both the extract (control) and the mixture (zinc nitrate + extract) were then calcined at $350^{\circ} \mathrm{C} \pm 10^{\circ} \mathrm{C}$ for 2 hours in a muffle furnace to obtain $\mathrm{ZnO}$ NPs. 


\section{Characterization}

The synthesized $\mathrm{ZnO}$ NPs were characterized using various spectroscopic and microscopic techniques. UV-visible spectrum was evaluated using UV-Visible spectrophotometer (Shimadzu UV-2450) and the spectrum was recorded between 300 and $800 \mathrm{~nm}$. Hydrodynamic (Z-average) size and polydispersity index (PDI) of the synthesized ZnO NPs were evaluated by Zeta sizer instrument (Malvern Zetasizer Nano ZS90), and the results were acquired by the Malvern ZS nano software. Fourier transform infrared (FTIR) analysis of the NPs was carried out with Fourier transform spectrometer (Shimadzu FT-IR Prestige-21 Model) at a frequency range of 4,000-500 $\mathrm{cm}^{-1}$. Crystalline structure was analyzed using X-ray diffractometer (Rigaku ZSX Primus II). Morphological analysis of the synthesized $\mathrm{ZnO}$ NPs coated with platinum was carried out using scanning electron microscope (SEM) (JOEL JSM 6335-F) equipped with $150 \mathrm{kV}$ acceleration voltage, and energy-dispersive X-ray spectroscopy (EDS) (Oxford Instruments AZTEC EDS) attached to the same instrument was used to ascertain the elemental composition and purity of the synthesized $\mathrm{ZnO}$ NPs.

\section{Antimicrobial activity}

Evaluation of antimicrobial activity of $A$. lebbeck $\mathrm{ZnO}$ NPs against five pathogenic microorganisms - two gram-positive, B. cereus (ATCC 7064) and S. aureus (6538 P), and three gram-negative, E. coli (O157:H7), K. pneumoniae (ATCC 27738), and S. typhi (B-4420) - was carried out on Muller-Hilton agar dishes using disc diffusion method. ${ }^{31}$ Ciprofloxacin $(10 \mu \mathrm{g} / \mathrm{disc})$ was used as a standard and sterile blank disc with $5 \mathrm{~mm}$ diameter infused with known concentration of $\mathrm{ZnO}$ NPs, extracts, and dimethylsulfoxide (DMSO) was used to ascertained the antibacterial activity. Pure culture of the microorganisms was provided by the Department of Food Engineering Laboratory, Faculty of Engineering, Ege University, Turkey.

\section{Antioxidant activity}

Antioxidant activity was carried out by hydrogen peroxide $\left(\mathrm{H}_{2} \mathrm{O}_{2}\right)$ free radical scavenging assay using the method of Pick and Mizel with some modifications..$^{32}$ Briefly, various concentrations $(100,75,50,25,12.5$, and $6.25 \mu \mathrm{g} / \mathrm{mL})$ of the synthesized ZnO NPs, extract, and ascorbic acid as standard, were mixed with $100 \mu \mathrm{L} \mathrm{H}_{2} \mathrm{O}_{2}$ solution $(5 \mathrm{mM})$, and the absorbance was read at $230 \mathrm{~nm}$ after 20 minutes of incubation. PBS without hydrogen peroxide was used as a blank solution. The percentage inhibition of $\mathrm{H}_{2} \mathrm{O}_{2}$ scavenging was calculated using the following equation:

$$
\% \mathrm{H}_{2} \mathrm{O}_{2} \text { free radicals }=\left[1-\left(\frac{A_{s}}{A_{c}}\right)\right] \times 100
$$

where $A_{c}$ is the absorbance of control and $A_{s}$ is the absorbance of sample.

\section{Cell culture}

Breast cancer cell lines MDA-MB 231 and MCF-7 were obtained from Professor Dr Mustafa Djamgoz (Imperial College London, UK), and the use of the cell lines was approved by Biotechnology Research Center Ethical Committee (BRCEC2011-01). Cells were cultured in DMEM (Gibco by Life Technology, Carlsbad, CA) supplemented with $10 \% 2 \mathrm{mM} \mathrm{L-glutamine,} \mathrm{and} \mathrm{penicillin/streptomycin.}$ The cells were constantly maintained under cell culture conditions of $37^{\circ} \mathrm{C}$ and $5 \% \mathrm{CO}_{2}$ in a humidified chamber. All the chemicals used for the cell culture are of analytical grades.

\section{Cytotoxicity and proliferation assay}

Cytotoxic activity of the ZnO NPs was evaluated by tryphan blue dye exclusion assay on breast cancer cell lines MDAMB 231 and MCF-7. ${ }^{33}$ The assay was performed to determine whether the $\mathrm{ZnO}$ NPs have toxic effect on the cell lines. The cells were plated in $35 \mathrm{~mm}$ dishes, incubated overnight, and treated with various concentrations $(100,50,25$, and $5 \mu \mathrm{g} /$ $\mathrm{mL}$ ) of the synthesized ZnO NPs. After the treatment, tryphan blue dye (4\%) was added into the $35 \mathrm{~mm}$ cell culture dishes and incubated for 10 minutes. Thirty random fields of view with at least 20 cells in each field were viewed at $100 \times$ using an inverted microscope (Leica DFC295) and the number of live vs dead cells was determined.

Antiproliferative activity of the synthesized ZnO NPs was analyzed using MTT reagent (Sigma-Aldrich) as previously described by Fraser et al with slight modifications. ${ }^{34}$ Briefly, cells (MDA-MB 231 and MCF-7) were plated in 12-well Falcon tissue plates at a density of $3 \times 10^{4}$ cells/well in $1 \mathrm{~mL}$ DMEM and allowed to settle overnight. After that, the DMEM was removed and replaced with various concentrations of ZnO NPs viz., 5, 25, 50, and $100 \mu \mathrm{g} / \mathrm{mL}$ (minimum three wells per each concentration), and then incubated for 24 hours. After the treatment periods, the medium was removed, and $0.15 \mathrm{~mL}$ MTT was added to $0.6 \mathrm{~mL}$ fresh medium. The plates were then wrapped in foil and incubated at $37^{\circ} \mathrm{C}$ for 3 hours. The medium containing the MTT was substituted with $0.89 \mathrm{~mL}$ DMSO and $0.11 \mathrm{~mL}$ glycine buffer. Absorbance was measured using Absorbance Microplate Reader (ELX 800 ${ }^{\mathrm{TM}}$ ) at a wavelength of $570 \mathrm{~nm}$ after 10 minutes. 


\section{Statistical analysis}

Data are given as means \pm standard errors of the mean (SEM). Graphical representations and statistical analysis were done using OriginPro (version 2016) and InStatGraphPad software (version 3). Statistical comparisons were determined using one-way ANOVA followed by Tukey-Kramer multiple comparison test, where necessary. All the experiments were carried out in triplicate and repeated at least three times ( $\mathrm{n} \geq 3$ ). $P<0.05$ was considered significant or $P>0.05$ insignificant and $P<0.0001$ was considered highly significant.

\section{Results and discussion}

In this present study, ZnO NPs were rapidly synthesized using A. lebbeck stem bark extract as bioreductant.

UV-vis spectroscopy was employed to analyze the formation of $\mathrm{ZnO}$ NPs from zinc nitrate solution, since there is a visible color change (from dark brown to light brown) that occurred, which indicates the formation of ZnO NPs (Figure 1). Intensity of the light brown color of the NPs increased with increase in the concentration of zinc nitrate, which could be due to the excitation of surface plasmon vibrations. ${ }^{35}$

UV-visible absorption of the synthesized ZnO NPs with various concentrations of zinc nitrate and $\mathrm{pH}$ at different incubation periods are shown in Figure 2A and B. The results of our study show that the absorption peak for the synthesized $\mathrm{ZnO}$ NPs is $368 \mathrm{~nm}$, and is in conformity with the range of light absorption of ZnO NPs, which is $360-380 \mathrm{~nm} .{ }^{36}$ Elham Zare et al reported the biosynthesis of $\mathrm{ZnO}$ NPs using cumin seeds and zinc nitrate, with an average size of $7 \mathrm{~nm}$ and UVvis absorption peak at $370 \mathrm{~nm} \cdot{ }^{30}$ Additionally, Singh et al also reported the green synthesis of $\mathrm{ZnO}$ NPs using Pseudomonas aeruginosa and zinc nitrate, with a size between 35 and $80 \mathrm{~nm}$ and UV-vis absorption at $360 \mathrm{~nm} \cdot{ }^{37}$ Also, some physicochemical parameters such as concentration of metal ions, $\mathrm{pH}$, and incubation period were studied to determine the suitable condition for the synthesis of $\mathrm{ZnO}$ NPs (Figure 2A and B).
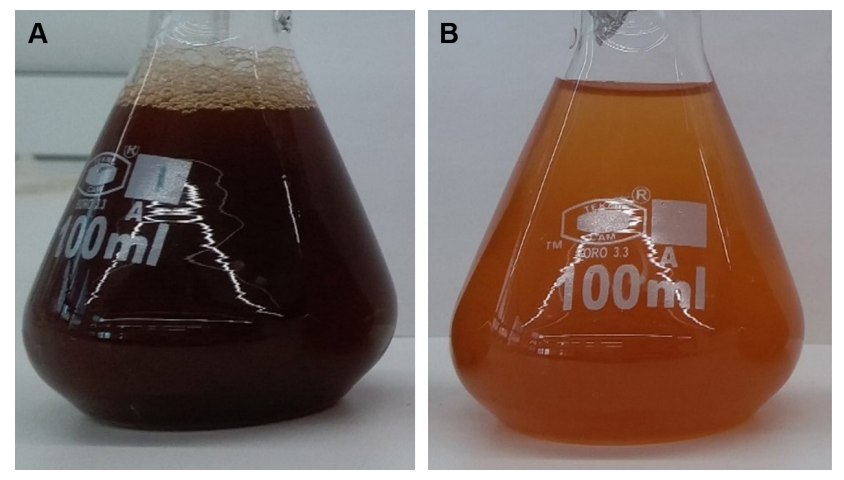

Figure I Synthesis of ZnO NPs: (A) Albizia lebbeck aqueous extract; (B) ZnO NPs. Abbreviation: $\mathrm{ZnO}$ NPs, zinc oxide nanoparticles.

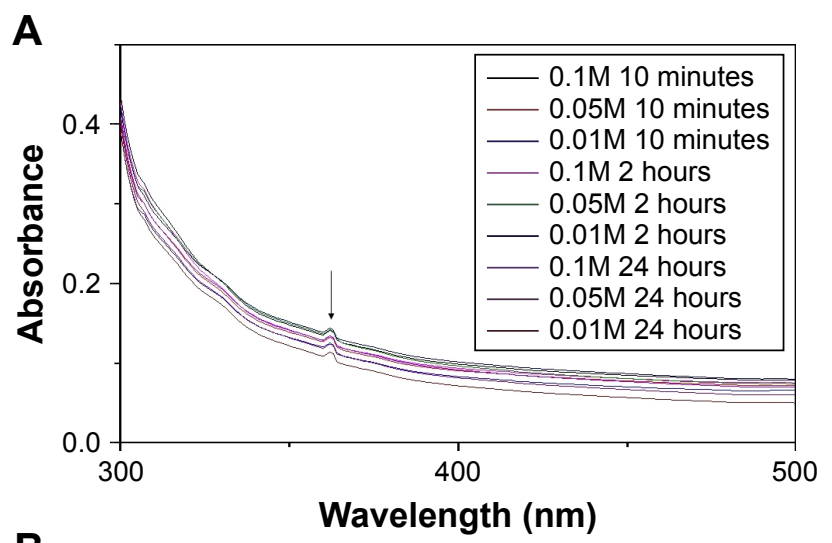

B

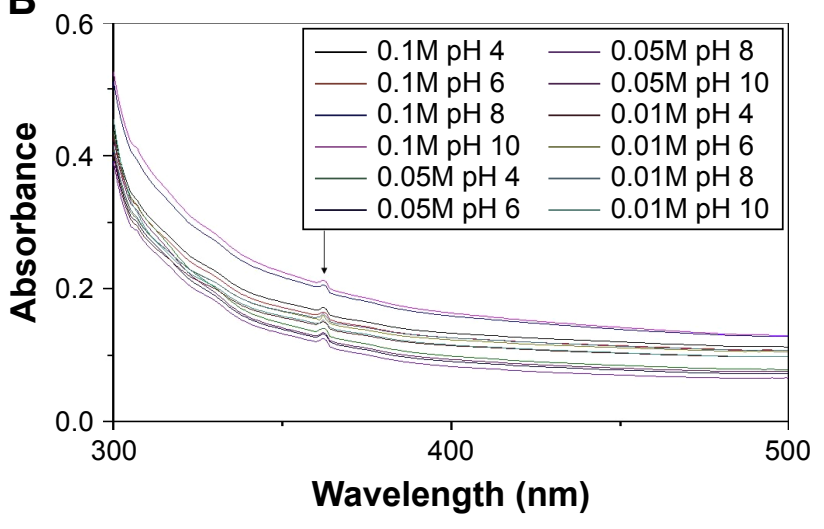

Figure 2 UV-visible spectra of ZnO NPs prepared with various concentrations of zinc nitrate at different $(\mathbf{A})$ incubation time and $(\mathbf{B}) \mathrm{pH}$.

Abbreviation: $\mathrm{ZnO}$ NPs, zinc oxide nanoparticles.

Increasing the concentrations of the metal ions (zinc nitrate) from 0.01 to $0.1 \mathrm{M}$ did not directly show any significant effect on the absorption peak but it revealed effect on the intensity of the synthesized $\mathrm{ZnO}$ NPs with increased metal ion concentrations. The $\mathrm{pH}$ was regulated using $0.1 \mathrm{M} \mathrm{NaOH}$ and $0.1 \mathrm{HCl}$. At $\mathrm{pH} 4,6$, and 8, the nanoparticle was synthesized but there was a slight shift in the absorption intensity of the synthesized $\mathrm{ZnO}$ NPs; however, at pH 10, no effect on both the intensity and the absorption peak of the nanoparticle was observed. Nagarajan et al revealed that, at lower $\mathrm{pH} 4-5$ and higher $\mathrm{pH} 10, \mathrm{ZnO}$ NPs synthesized using seaweed did not show absorption. ${ }^{36}$ The presence of absorption peaks at those $\mathrm{pH}$ in our study could be a result of high carboxylic acid content present in $A$. lebbeck stem bark extract. ${ }^{29}$ Similarly, measuring the UV-vis spectra of the synthesized $\mathrm{ZnO}$ NPs at different time intervals after the synthesis did not show any effect on the absorption peak and intensity (Figure 2A), and it reflects the stability of the synthesized ZnO NPs as suspension after 24 hours.

Hydrodynamic size distribution results of the $\mathrm{ZnO}$ NPs were obtained by the dynamic light scattering analysis of the particles to confirm the synthesis of the NPs; the Z-average size of the $0.05 \mathrm{M}$ and $0.1 \mathrm{M} \mathrm{ZnO} \mathrm{NPs}$ was $82.31 \mathrm{~nm}$ and average PDI was 0.262 (Figure $3 \mathrm{~A}$ and $\mathrm{B}$ ). The $Z$-average of $0.01 \mathrm{M}$ 
A Size distribution by intensity

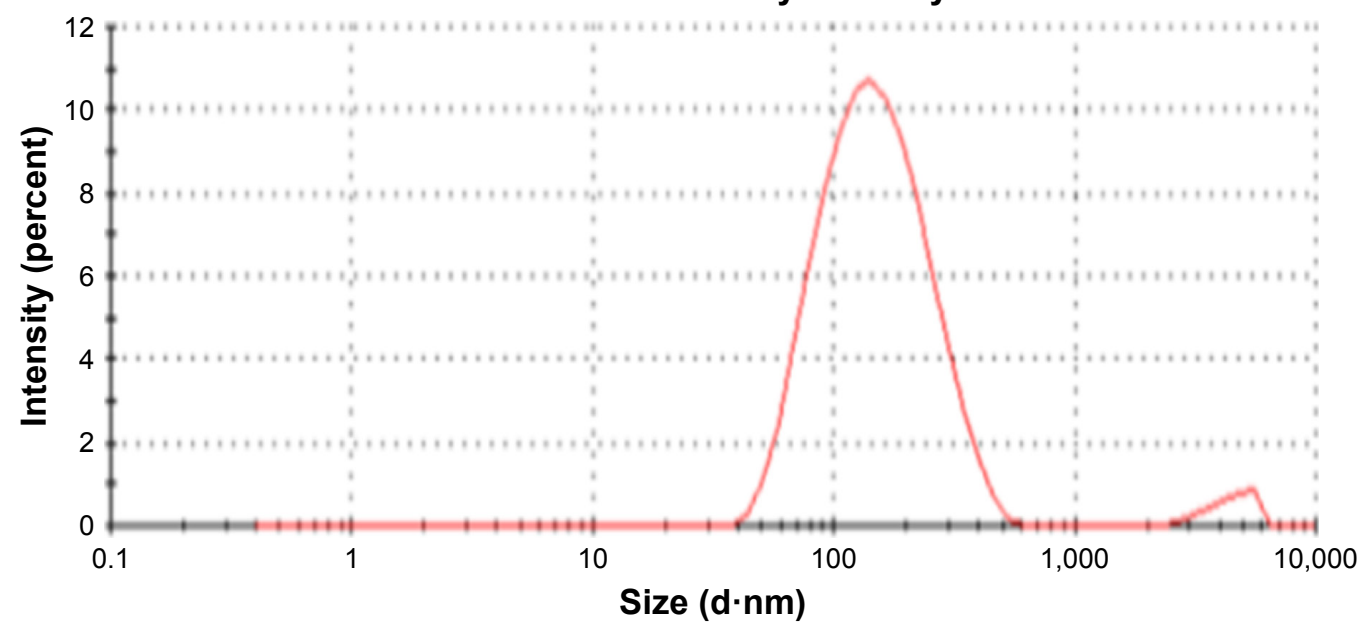

B

Size distribution by intensity

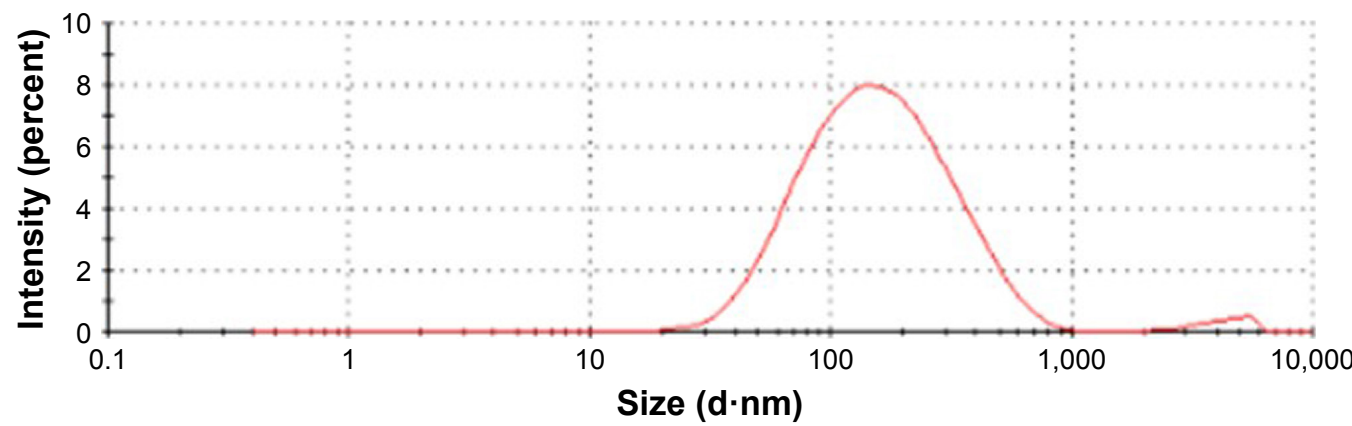

C

Size distribution by intensity

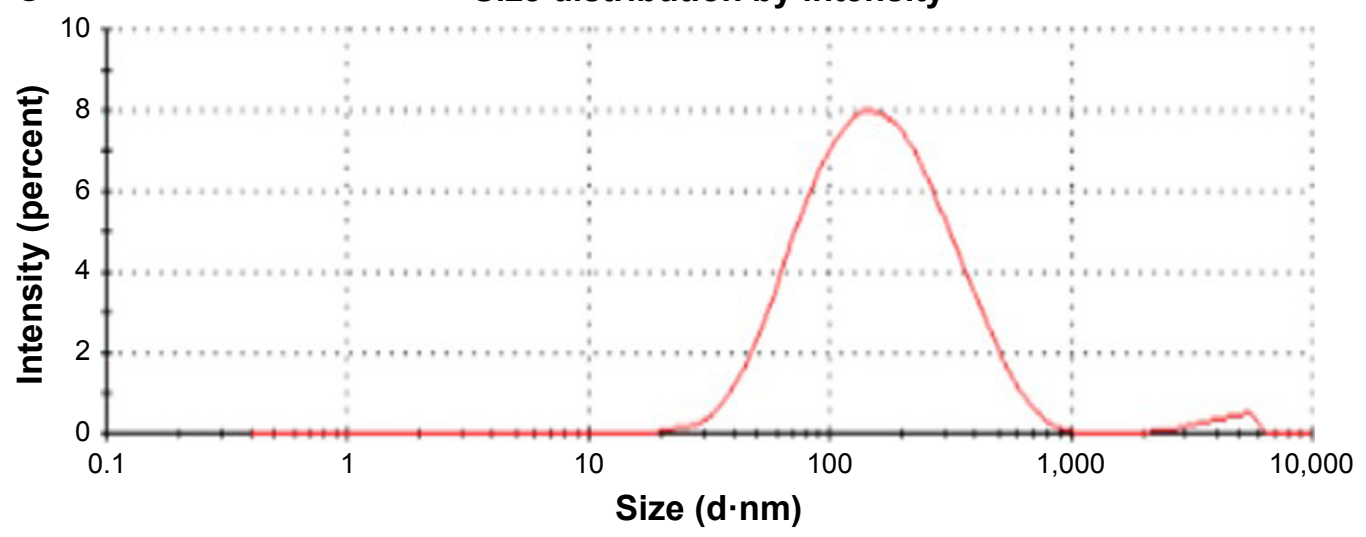

Figure 3 Particle size distribution of synthesized ZnO NPs using Albizia lebbeck stem bark extract: (A) $0.1 \mathrm{M}$, (B) $0.05 \mathrm{M}$, and (C) $0.01 \mathrm{M}$. Abbreviation: $\mathrm{ZnO}$ NPs, zinc oxide nanoparticles.

synthesized NPs was $110 \mathrm{~nm}$, and PDI was 0.326 (Figure 3C). Our zeta sizer results clearly reveal that the synthesized $\mathrm{ZnO}$ NPs are monodispersed in nature due to their broad size distribution and show PDI values of $<0.7$, and this confirmed the monodispersity of ZnO NPs. ${ }^{38}$ Particle size can be elucidated more with transmission electron microscope or SEM. ${ }^{39}$ The result obtained was almost similar to our SEM data.

FTIR analysis of the synthesized $\mathrm{ZnO}$ NPs was carried out at room temperature and a frequency range between 400 and $4,500 \mathrm{~cm}^{-1}$. The FTIR spectra show the composition of the bioactive molecules of $A$. lebbeck and their distribution on the surface of the ZnO NPs. Synthesized ZnO NPs and A. lebbeck spectra, shown in Figure 4, revealed the different absorption bands of the NPs and the plant extract, respectively. Wide absorption bands around $3,356 \mathrm{~cm}^{-1}$ were associated with $\mathrm{O}-\mathrm{H}$ bending of the water molecules, which were adsorbed on the sample. ${ }^{40}$ FTIR spectrum of the $\mathrm{ZnO}$ NPs $(0.01 \mathrm{M}, 0.05 \mathrm{M}$, and $0.1 \mathrm{M})$ prepared with 


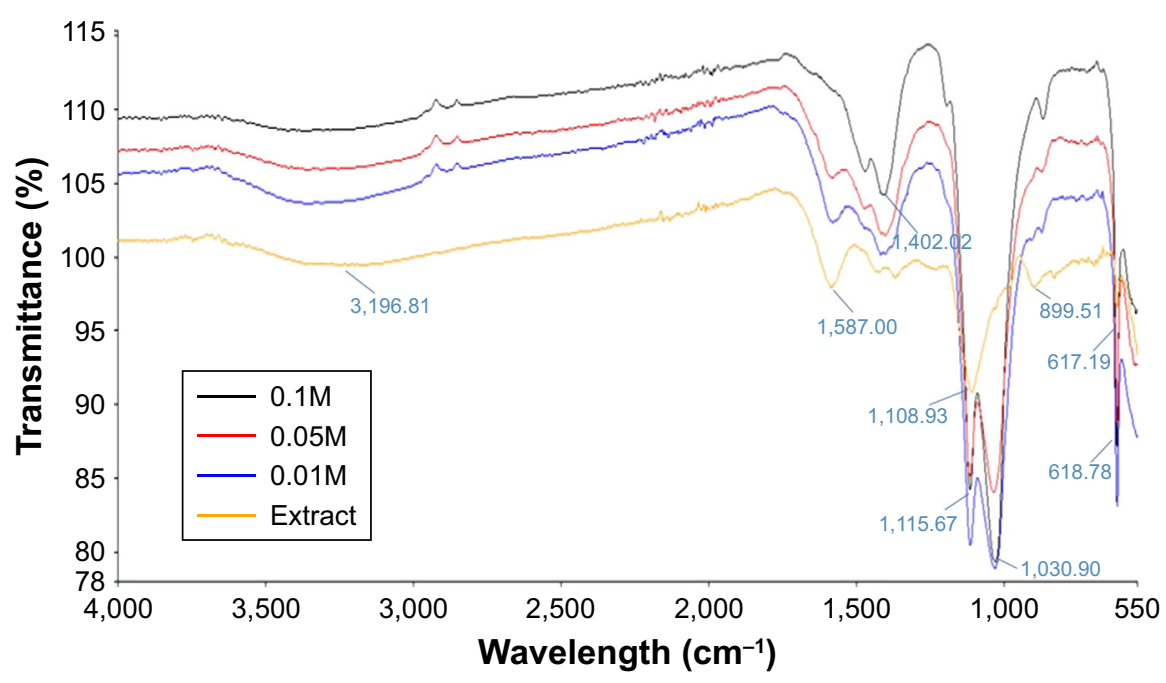

Figure 4 FTIR spectra of Albizia lebbeck extract and synthesized $\mathrm{ZnO}$ NPs using various concentrations of zinc nitrate. Abbreviations: FTIR, Fourier transform infrared; ZnO NPs, zinc oxide nanoparticles.

the $A$. lebbeck extract absorbed at 1,402,1,115, 1,030, and $618 \mathrm{~cm}^{-1}$. The absorption peak at $1,402 \mathrm{~cm}^{-1}$ correspond to $\mathrm{C}=\mathrm{CH}$ stretching of methyl group, and $1,030 \mathrm{~cm}^{-1}$ implies the presence of $\mathrm{C}=\mathrm{O}$ amide band of aliphatic carboxylic acid. The absorption peak observed at $1,030 \mathrm{~cm}^{-1}$ can be attributed to $\mathrm{C}-\mathrm{O}$ of primary saturated alcohol. The bands observed at $618 \mathrm{~cm}^{-1}$ correspond to $\mathrm{Zn}-\mathrm{O}$ bond, which confirms that the synthesized nanoparticle is a ZnO NP. ${ }^{41}$ Our FTIR analysis revealed that carboxylic acid and alcoholic compounds are capable of binding metals, and may form metal NPs through stabilizing the medium and preventing agglomeration. ${ }^{23}$

Phase purity of the various concentrations of the biosynthesized ZnO NPs using $A$. lebbeck extract was studied using $\mathrm{X}$-ray diffraction (XRD). Figure 5 shows the XRD spectrum of the biosynthesized $\mathrm{ZnO}$ NPs. The main peaks obtained at $100,002,101,102,110,103,112,004$, and 104 correspond to Bragg reflections with $2 \theta$ values of $31.70^{\circ}, 34.34^{\circ}$, $36.16^{\circ}, 47.54^{\circ}, 56.48^{\circ}, 62.78^{\circ}, 67.66^{\circ}, 72.53^{\circ}$, and $76.58^{\circ}$

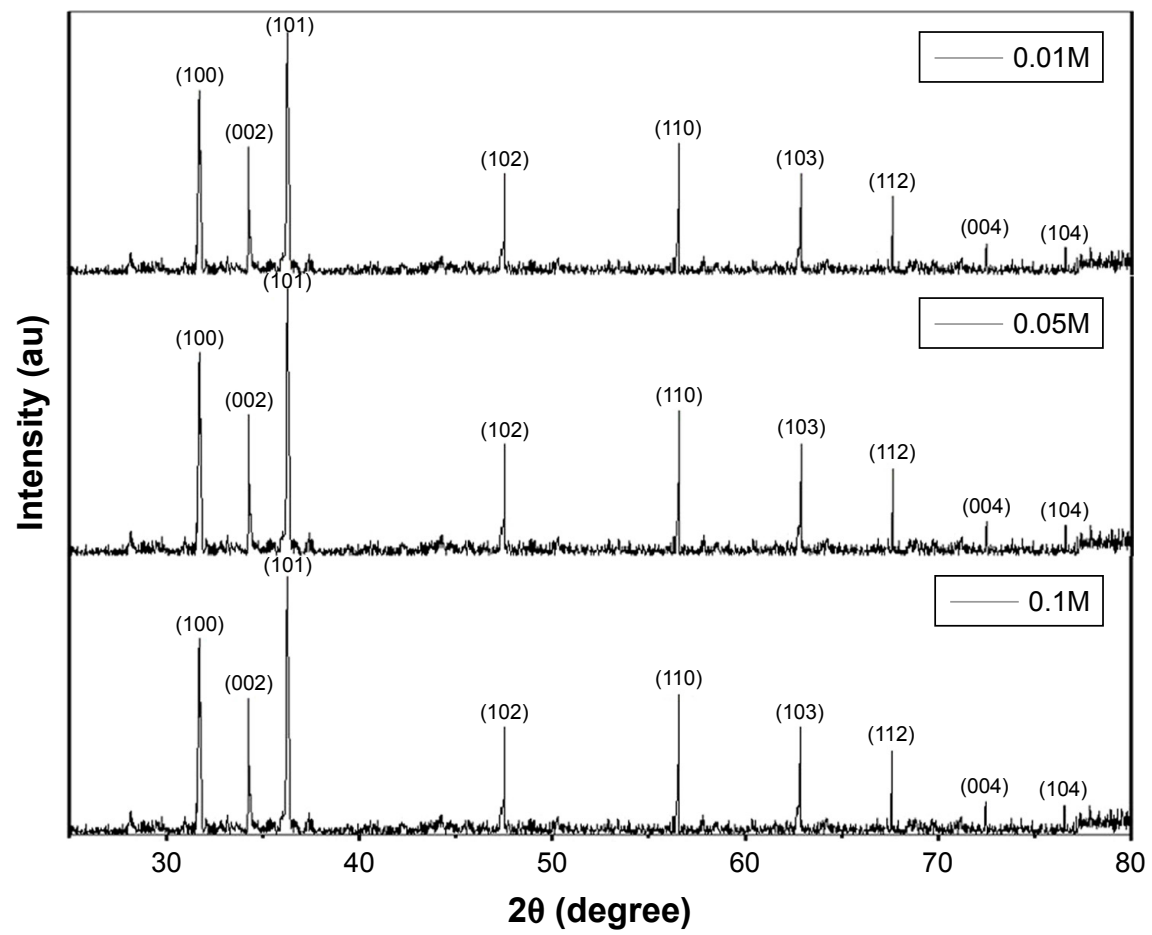

Figure 5 XRD pattern of $0.01 \mathrm{M}, 0.05 \mathrm{M}$, and $0.1 \mathrm{M}$ synthesized $\mathrm{ZnO}$ NPs.

Abbreviations: XRD, X-ray diffraction; ZnO NPs, zinc oxide nanoparticles. 
respectively. The presence of the peaks confirms the formation of highly purified ZnO NPs. Synthesized ZnO NPs using various concentrations of $0.01 \mathrm{M}, 0.05 \mathrm{M}$, and $0.1 \mathrm{M}$ reveal similar XRD spectrum pattern. The XRD spectrum obtained indicates the absence of impurities. Furthermore, the pattern shows that the $\mathrm{ZnO}$ NPs were synthesized using natural source. ${ }^{30}$

The surface morphology of synthesized ZnO NPs was explored using SEM. Typical SEM micrographs display many agglomerated particles with irregular spherical morphology, and the various concentrations of $0.1 \mathrm{M}, 0.05 \mathrm{M}$, and $0.01 \mathrm{M} \mathrm{ZnO} \mathrm{NPs} \mathrm{reveal} \mathrm{average} \mathrm{diameter} \mathrm{sizes} \mathrm{of} 66.25$, 82.52, and $112.87 \mathrm{~nm}$, respectively (Figure 6A-C). The $\mathrm{ZnO}$ NPs appear to be more agglomerated, and some of the crystals are more visible in Figure 6A. In Figure 6B, the particles reveal slight agglomeration of zinc oxides and appear to be elongated and hexagonal shaped, and some particles in Figure 6C appear to be elongated and rod-like shaped. Raut et al synthesized $\mathrm{ZnO}$ NPs using Ocimum tenuiflorum extract, which revealed hexagonal and rod-shaped NPs with size ranging between 11 and $25 \mathrm{~nm}^{42}$

Energy-dispersive X-ray (EDX) spectra revealed the surface chemical composition of the synthesized ZnO NPs. Three clear signals of $\mathrm{Zn}$ and one signal of $\mathrm{C}, \mathrm{O}, \mathrm{Na}, \mathrm{P}$, and $\mathrm{K}$ were observed in both particles, but there is a presence of an additional signal of $\mathrm{S}$ in $0.05 \mathrm{M}$ and two signals of $\mathrm{Mg}$ and $\mathrm{Cl}$ in $0.01 \mathrm{ZnO}$ NPs (Figure 6D-F). The presence of small signals of $\mathrm{C}, \mathrm{O}, \mathrm{P}, \mathrm{K}, \mathrm{S}, \mathrm{Mg}$, and $\mathrm{Cl}$ in the EDX spectrum confirmed the presence of the bioactive compounds of
A

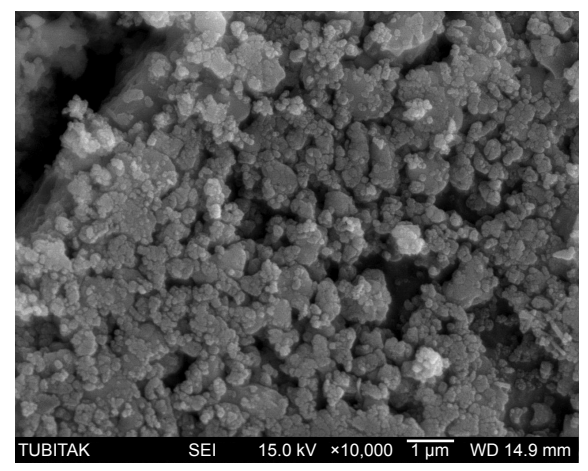

B

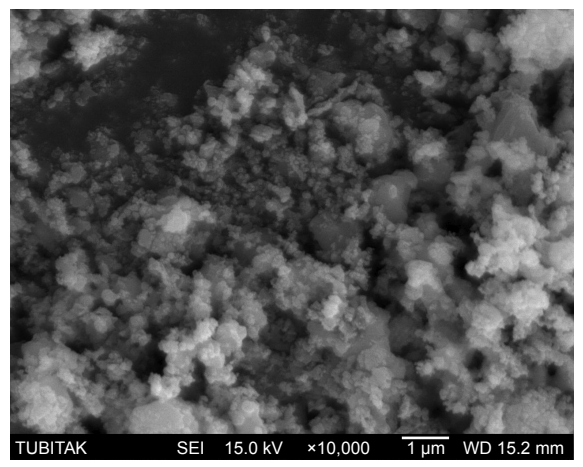

C

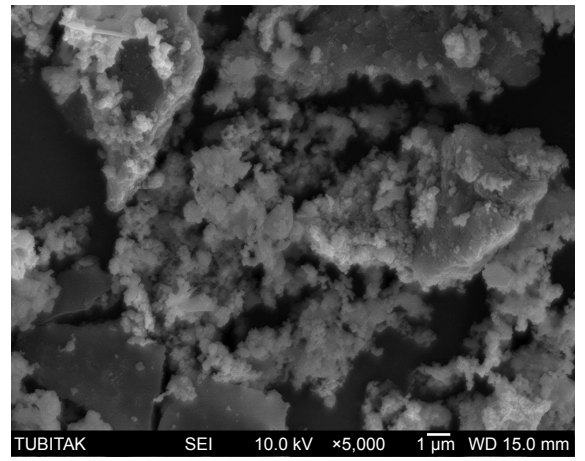

D

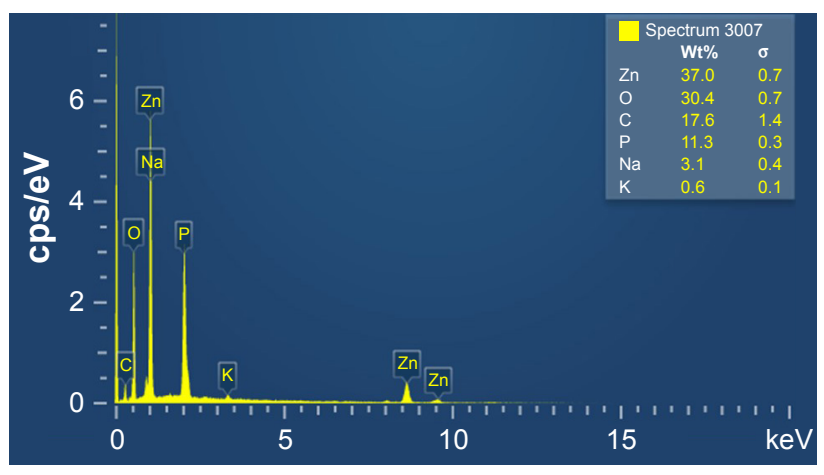

E

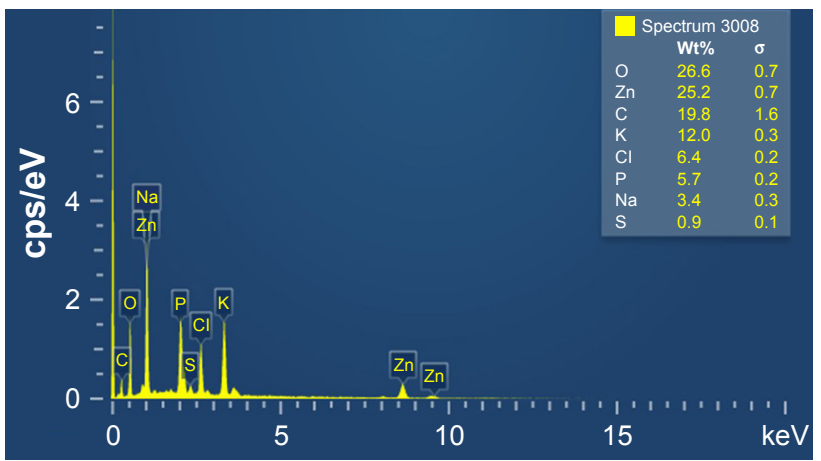

F

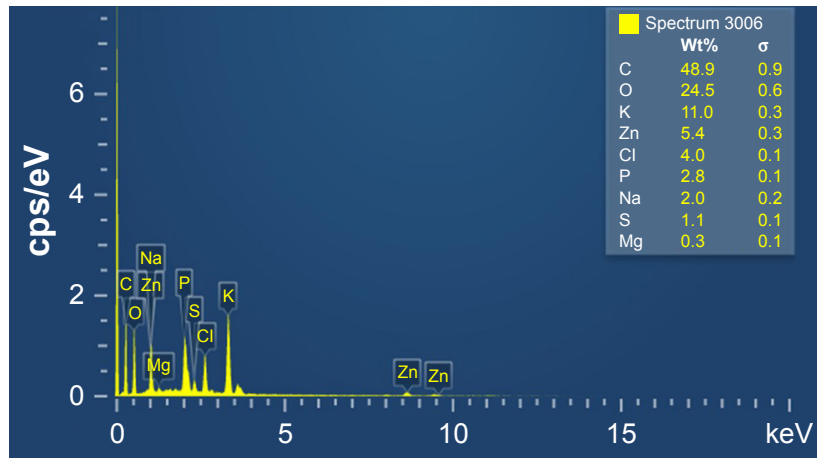

Figure 6 SEM images of ZnO NPs synthesized using Albizia lebbeck stem bark extract: (A) 0.1 M, (B) $0.05 M$, and (C) 0.01 M. EDX spectra of the ZnO NPs: (D) 0.1 M, (E) 0.05M, and (F) 0.01M.

Abbreviations: EDX, energy-dispersive X-ray spectroscopy; SEM, scanning electron microscope; ZnO NPs, zinc oxide nanoparticles; cps/eV, counts per second per electron-volt. 
Table I Antimicrobial activity of ZnO NPs in comparison with extract, zinc nitrate solution, DMSO, and antibiotics

\begin{tabular}{|l|l|l|l|l|l|}
\hline Bacterial strains & $\begin{array}{l}\text { Bacillus cereus } \\
\text { (mean } \pm \text { SEM) }\end{array}$ & $\begin{array}{l}\text { Staphylococcus aureus } \\
\text { (mean } \pm \text { SEM) }\end{array}$ & $\begin{array}{l}\text { Escherichia coli } \\
\text { (mean } \pm \text { SEM) }\end{array}$ & $\begin{array}{l}\text { Klebsiella pneumoniae } \\
\text { (mean } \pm \text { SEM) }\end{array}$ & $\begin{array}{l}\text { Salmonella typhi } \\
\text { (mean } \pm \text { SEM) }\end{array}$ \\
\hline $\begin{array}{l}\text { Standard ciprofloxacin } \\
(10 \mu g / \text { disc) }\end{array}$ & $10.7 \pm 0.56$ & $10.3 \pm 0.56$ & $14.0 \pm 0.20$ & $11.0 \pm 0.30$ & $12.53 \pm 0.50$ \\
\hline ZnO NPs (0.IM) & $8.83 \pm 0.42$ & $4.50 \pm 0.30^{* *}$ & $9.13 \pm 0.41^{* *}$ & $7.30 \pm 0.29^{* *}$ & $10.57 \pm 0.320$ \\
\hline ZnO NPs (0.05M) & $5.5 \pm 0.50^{* *}$ & $5.67 \pm 0.29^{* *}$ & $7.67 \pm 0.47^{* *}$ & $3.33 \pm 0.28^{* *}$ & $6.5 \pm 0.20^{* *}$ \\
\hline ZnO NPs (0.0IM) & $3.33 \pm 0.29^{* *}$ & $2.00 \pm 0.22^{* *}$ & $4.67 \pm 0.15^{* *}$ & $3.67 \pm 0.21^{* *}$ & $1.00 \pm 0.10^{* *}$ \\
\hline Albizia lebbeck extract & $1.0 \pm 0.20^{* *}$ & $1.5 \pm 0.20^{* *}$ & $0.3 \pm 0.15^{* *}$ & $1.0 \pm 0.10^{* *}$ & $0.97 \pm 0.3 I^{* *}$ \\
\hline Zinc nitrate solution (0.IM) & $2.67 \pm 0.15^{* *}$ & $2.33 \pm 0.29^{* *}$ & $1.0 \pm 0.10^{* *}$ & $1.33 \pm 0.21^{* *}$ & $1.0 \pm 0.20^{* *}$ \\
\hline DMSO (30\%) & - & - & & - & - \\
\hline
\end{tabular}

Notes: Results are presented as mean \pm SEM of inhibition zone $(\mathrm{mm})$ of at least triplicates $(\mathrm{n} \geq 3)$. $* * P<0.01$ vs control (standard group). $(-)$ indicates no significant antibacterial activity.

Abbreviations: DMSO, dimethylsulfoxide; SEM, standard error of mean; ZnO NPs, zinc oxide nanoparticles.

A. lebbeck stem bark on the surface of the synthesized $\mathrm{ZnO}$ NPs, and the Na signal in both particles could as a result of $\mathrm{pH}$ regulation during the synthesis of the NPs. Elemental mapping analysis of the synthesized $\mathrm{ZnO}$ NPs revealed $37 \%$ distribution of zinc in $0.1 \mathrm{M}, 25.2 \%$ in $0.05 \mathrm{M}$, and $5.4 \%$ in $0.01 \mathrm{M}$. The EDS results revealed the highest proportion of zinc in $0.1 \mathrm{M}$ and $0.05 \mathrm{M}$, and could ascertain the green synthesis of ZnO NPs. Additionally, the optical absorption signals of zinc shown by the synthesized ZnO NPs were due to plasmon resonance of $\mathrm{ZnO}$ NPs. ${ }^{36}$

\section{Antimicrobial activity}

The results of the antimicrobial activities of the synthesized $\mathrm{ZnO}$ NPs, extract, zinc nitrate solution, DMSO, and antibiotics evaluated using agar disc diffusion method against five pathogenic bacterial strains are shown in Table 1.

While analyzing the antimicrobial activities of the synthesized $\mathrm{ZnO}$ NPs, we observed that the inhibitory effects of $0.1 \mathrm{M} \mathrm{ZnO} \mathrm{NPs} \mathrm{against} \mathrm{B.} \mathrm{cereus} \mathrm{and} \mathrm{S.} \mathrm{typhi} \mathrm{revealed}$ no significant difference when compared with those of ciprofloxacin (standard), and significant differences were observed against $S$. aureus, E. coli, and $K$. pneumoniae (Table 1 and Figure 7). The lower concentrations of $\mathrm{ZnO}$
NPs demonstrated moderate inhibitory effect against both gram-negative and gram-positive bacteria tested. The A. lebbeck aqueous extract showed mild activity, and zinc nitrate solution revealed moderate to mild activity against all the bacterial strains tested. DMSO used a solvent did not demonstrate any antibacterial activity (Table 1).

The results revealed that gram-negative bacteria are less resistant to $\mathrm{ZnO}$ NPs treatments than gram-positive bacteria, and this could attributed to the presence of a thick layer in the cell walls (peptidoglycan) of the latter group. Sinha et al studied the effect of ZnO NPs on halophilic and mesophilic bacterial species and revealed that Enterobacteria, which is gram-negative, is more sensitive to these NPs than B. subtilis, which is gram-positive bacteria; They concluded that the resistance in gram-positive bacteria is due to the presence of a thick layer of peptidoglycan in their cell wall. ${ }^{43}$ Elham Zare et al also found a strong antibacterial potential against gram-negative bacteria using ZnO NPs synthesized from cumin seeds, and concluded that the slight resistance of gram-positive bacteria is due the presence of a thick layer of peptidoglycan in their cell wall, ${ }^{30}$ which is similar to the results achieved in this study. It has been reported that binding of zinc ion to the bacterial cell membrane and
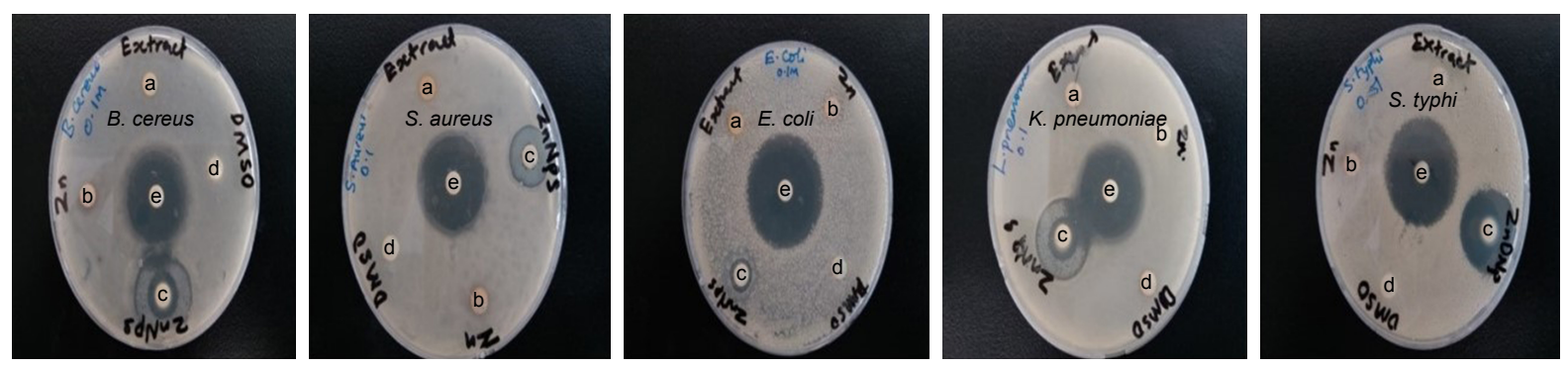

Figure 7 Zone of inhibition of 0.IM synthesized ZnO NPs compared with extract, zinc nitrate solution, DMSO, and antibiotics: (a) extract, (b) zinc nitrate solution, (c) ZnO NPs, (d) DMSO, and (e) antibiotic (ciprofloxacin).

Abbreviations: DMSO, dimethylsulfoxide; $\mathrm{ZnO}$ NPs, zinc oxide nanoparticles. 
production of reactive oxygen species (ROS) inside the cell result in the disruption of the cell. ${ }^{30}$

\section{Antioxidant activity}

Antioxidant activity of the nanoparticles was studied using $\mathrm{H}_{2} \mathrm{O}_{2}$ free radical scavenging assay.

The results of the antioxidant activities of the ZnO NPs analyzed spectrophotometrically using $\mathrm{H}_{2} \mathrm{O}_{2}$ free radical scavenging assay are shown in Figure 8. The $\mathrm{H}_{2} \mathrm{O}_{2}$ activity of ascorbic acid, $0.1 \mathrm{M} \mathrm{ZnO} \mathrm{NPs,} 0.05 \mathrm{M} \mathrm{ZnO} \mathrm{NPs,} 0.01 \mathrm{M} \mathrm{ZnO}$ $\mathrm{NPs}$, and extract revealed $\mathrm{IC}_{50}$ values of 45.7, 48.5, 48.7, 60.2, and $66.6 \mu \mathrm{g} / \mathrm{mL}$, respectively. Additionally, $0.1 \mathrm{M} \mathrm{ZnO} \mathrm{NPs}$ revealed the highest percentage inhibition among the NPs, followed by $0.05 \mathrm{M} Z \mathrm{ZnO}$ NPs. The percentage inhibition shown by $0.1 \mathrm{M} \mathrm{ZnO} \mathrm{NPs} \mathrm{is} \mathrm{close} \mathrm{to} \mathrm{that} \mathrm{of} \mathrm{ascorbic} \mathrm{acid} \mathrm{(standard),}$ which could be due to increase in zinc ion concentration. The synthesized ZnO NPs revealed a concentration-dependent effect in $\mathrm{H}_{2} \mathrm{O}_{2}$ free radical scavenging activity. The extract revealed the lowest antioxidant activity as shown in Figure 8A. Increase in the antioxidant activity of the biosynthesized $\mathrm{ZnO}$ NPs when compared with the plant might be a result of metal ions present in the particles; the possible predicted mechanism is illustrated in Figure 8B. It has been reported that enzymes utilizing metal ion $(\mathrm{Zn})$ as a cofactor scavenge $\mathrm{H}_{2} \mathrm{O}_{2}$ free

\section{A}

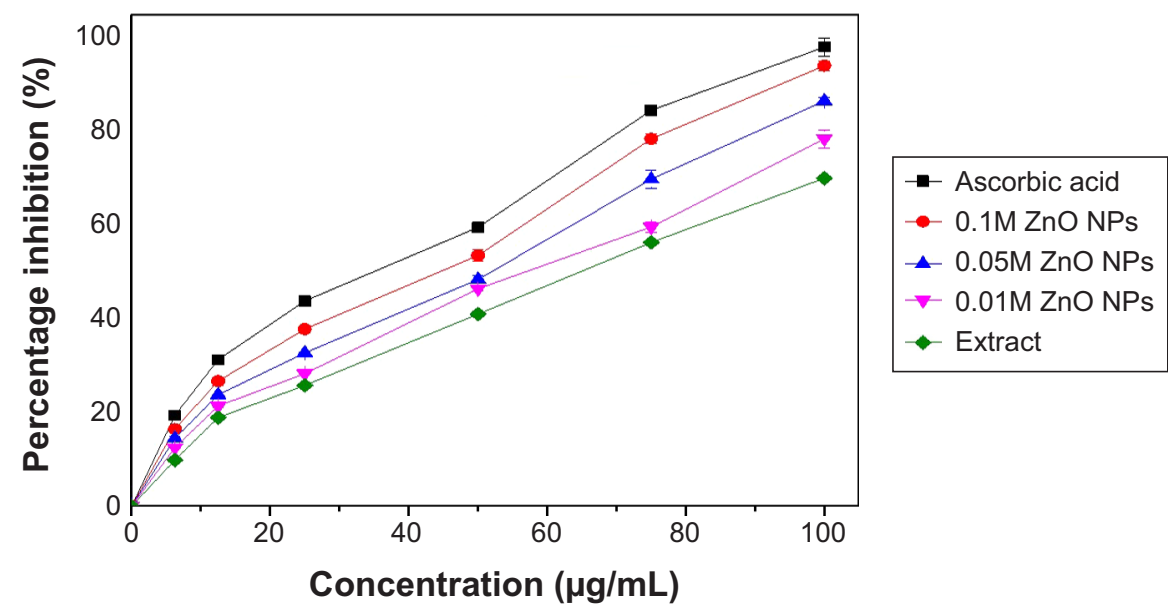

B

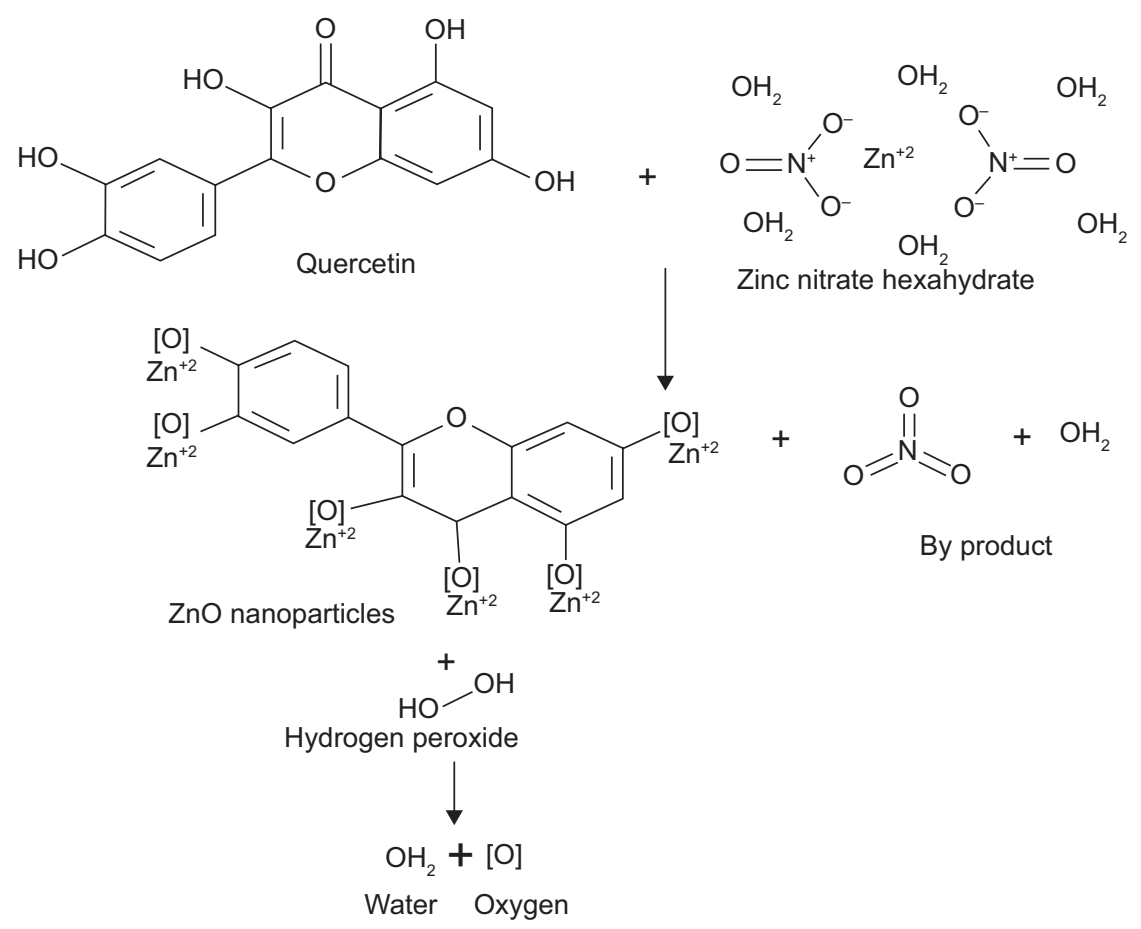

Figure $8 \mathrm{H}_{2} \mathrm{O}_{2}$ free radical scavenging activity of the biosynthesized $\mathrm{ZnO}$ NPs.

Notes: (A) $\mathrm{H}_{2} \mathrm{O}_{2}$ free radical scavenging activity of the biosynthesized $\mathrm{ZnO}$ NPs. (B) Predicted mechanism of $\mathrm{ZnO} N P s$ formation and its $\mathrm{H}_{2} \mathrm{O}_{2}$ free radical scavenging activity. Abbreviation: $\mathrm{ZnO}$ NPs, zinc oxide nanoparticles. 
radicals, and the presence of $\mathrm{Zn}$ ion in particles might be responsible for higher $\mathrm{H}_{2} \mathrm{O}_{2}$ free radical scavenging activity when compared with the plant. ${ }^{44}$ Parashant et al revealed that phenolic compounds present in plant extracts always demonstrated high antioxidant activity and they plays an important role in the green synthesis of nanoparticles. ${ }^{45}$

\section{In vitro cytotoxic and antiproliferative activity}

ZnO NPs were screened for cytotoxic activity against strongly metastatic and weakly metastatic breast cancer
(BCa) cell lines, MDA-MB 231 and MCF-7 cells, respectively. Tryphan blue exclusion assay was carried out to ascertain the effects of different concentrations $(5,25,50$, and $100 \mu \mathrm{g} / \mathrm{mL}$ ) of $0.1 \mathrm{M}, 0.05 \mathrm{M}$, and $0.01 \mathrm{M} \mathrm{ZnO} \mathrm{NPs} \mathrm{on}$ the viability of MDA-MB 231 and MCF-7 cells after 24-hour incubation period. The results showed that synthesized $\mathrm{ZnO}$ NPs significantly inhibited the viability of MDA-MB 231 cells with increased concentration when compared with control $(P<0.001, \mathrm{n} \geq 3$, Figure 9A). Typical phase-contrast light-microscopy images of ZnO NPs-treated MDA-MB 231 cells and controls obtained from tryphan blue assays are
A

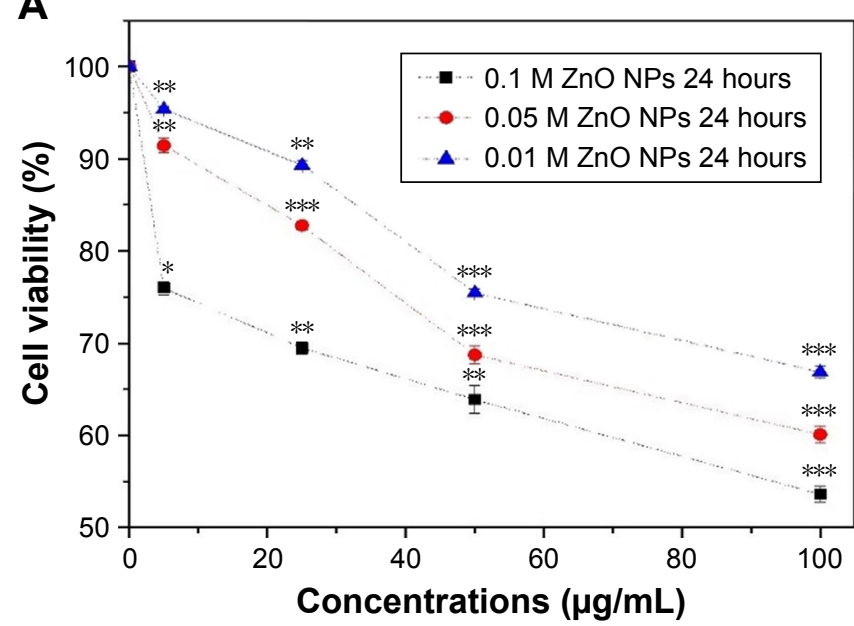

C

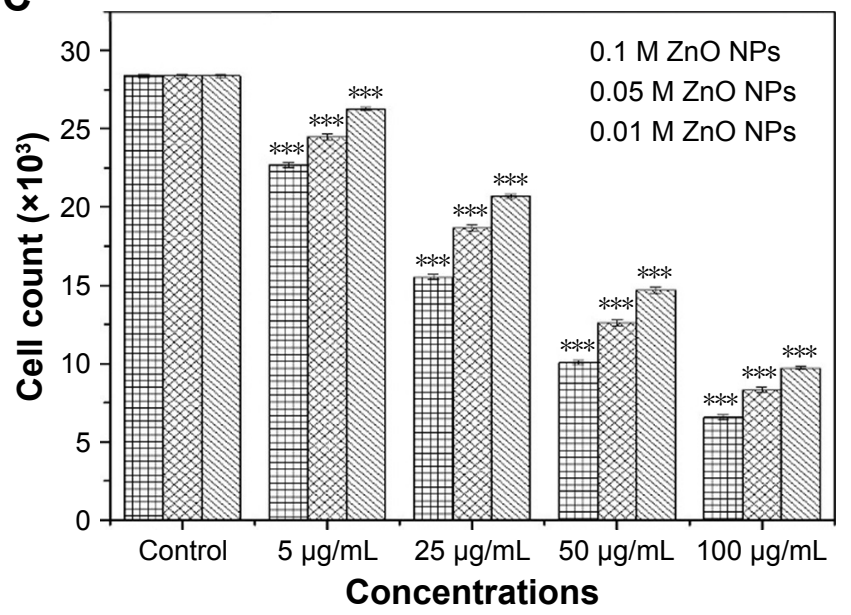

B

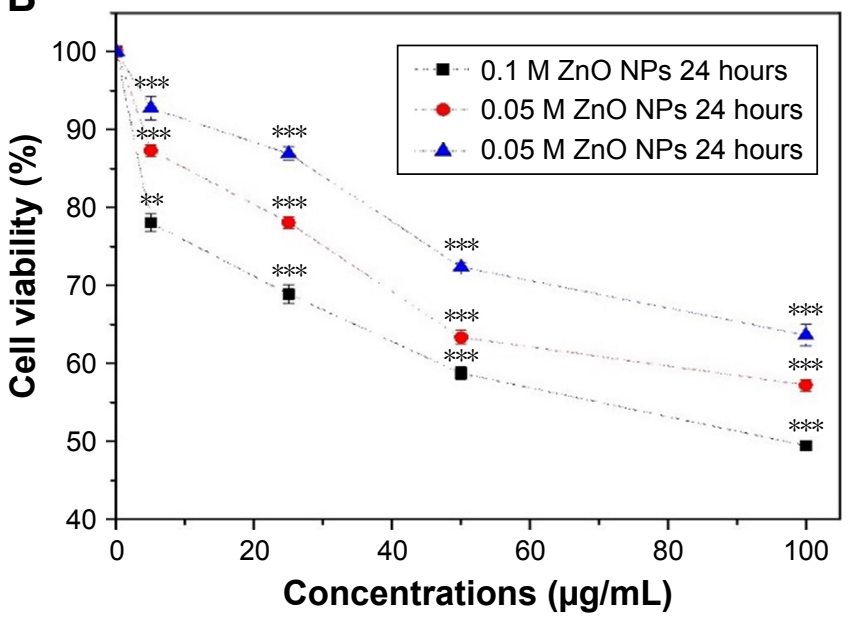

D

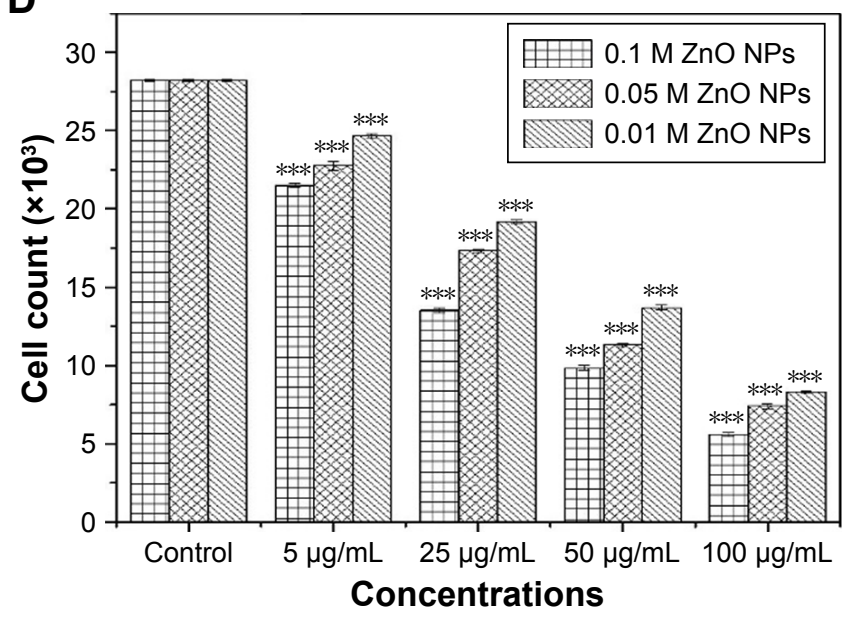

E

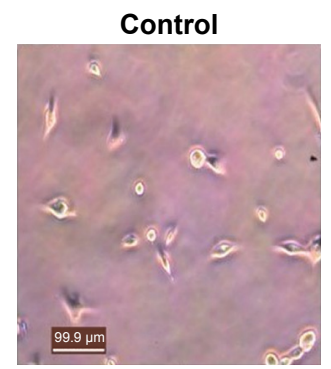

$5 \mu \mathrm{g} / \mathrm{mL}$

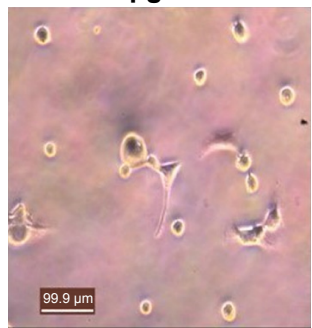

$25 \mu \mathrm{g} / \mathrm{mL}$

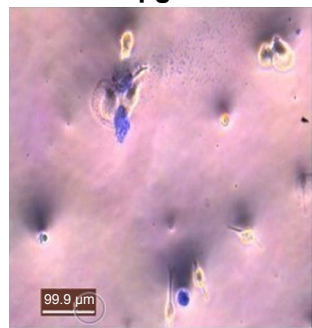

$50 \mu \mathrm{g} / \mathrm{mL}$

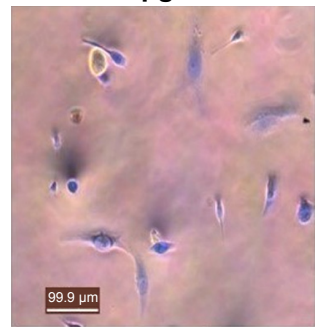

$100 \mu \mathrm{g} / \mathrm{mL}$

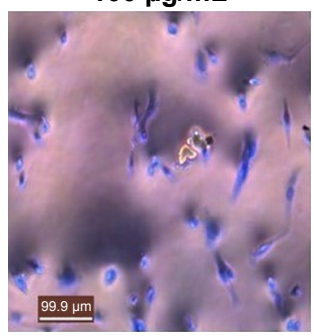



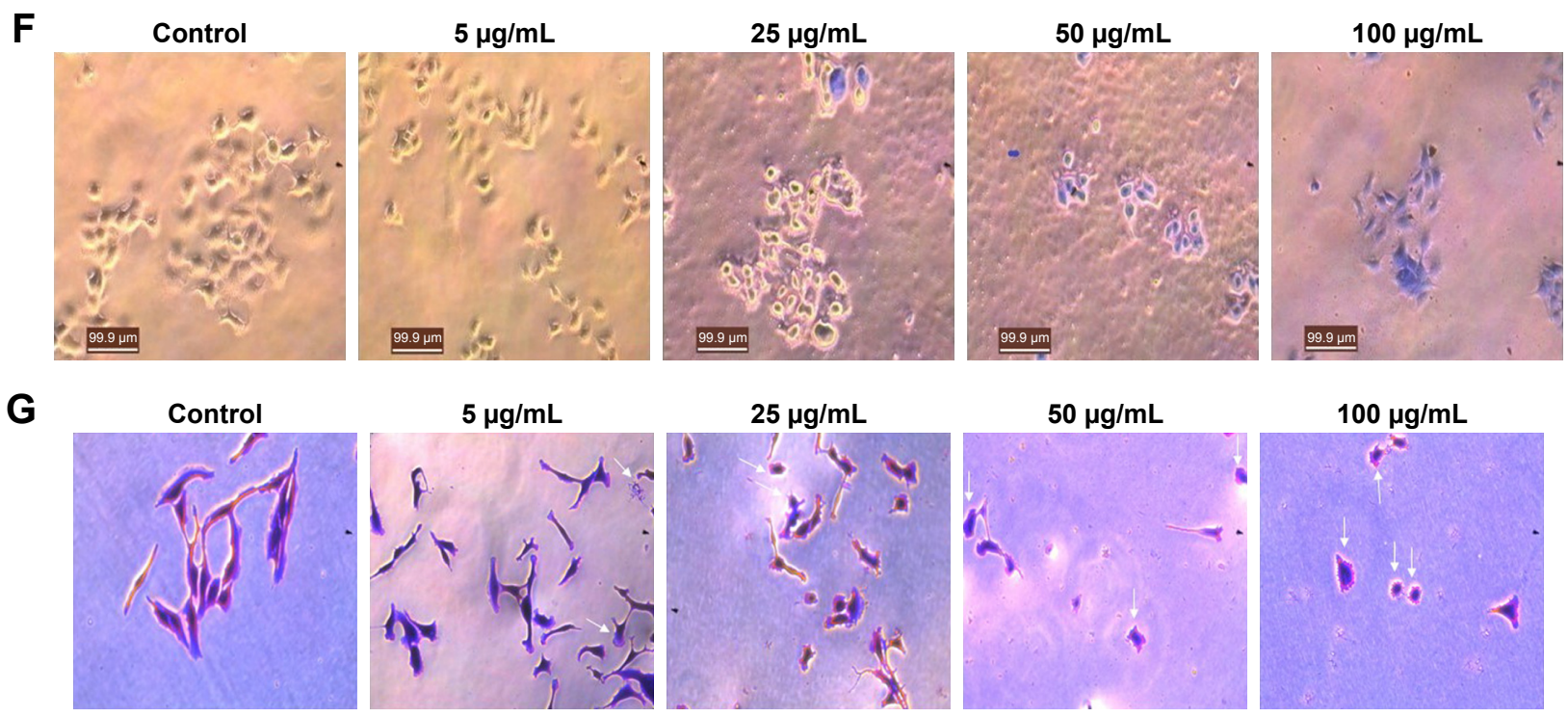

H
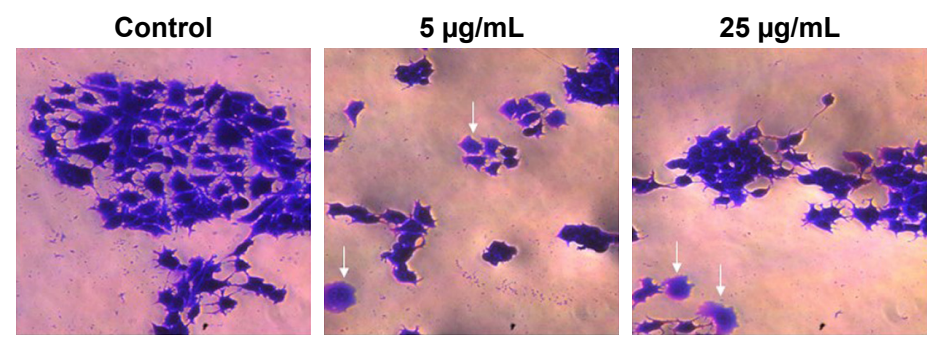

$50 \mu \mathrm{g} / \mathrm{mL}$

$100 \mu \mathrm{g} / \mathrm{mL}$

I

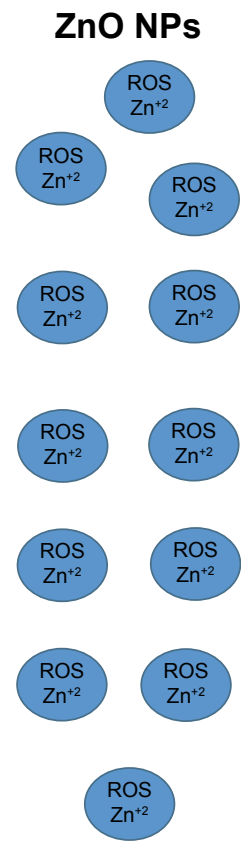

Cytotoxic activity
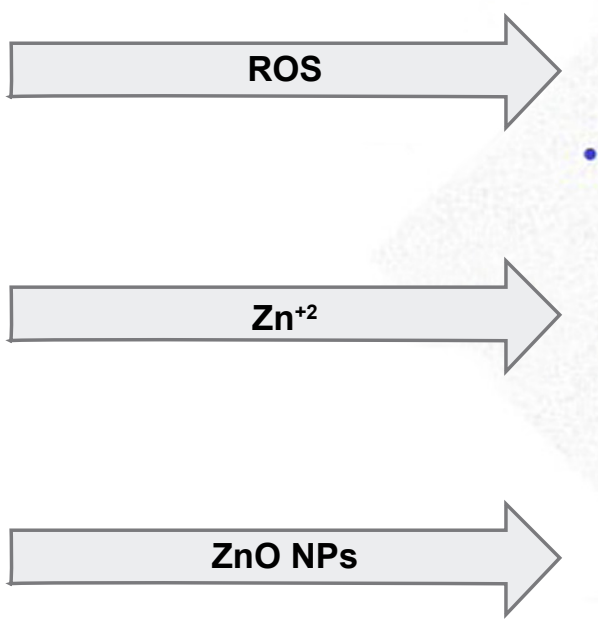

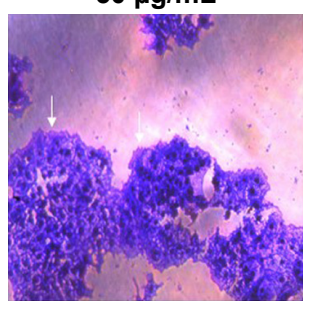

\section{Breast cancer cell}

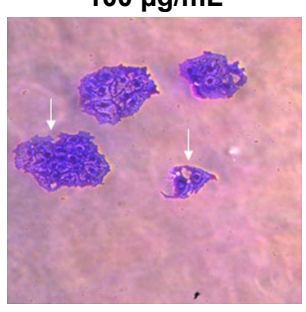

\section{Breast cancer cell}

$\begin{array}{cc}\mathrm{H}_{2} \mathrm{O}_{2} & \mathrm{H}_{2} \mathrm{O}_{2} \\ \mathrm{H}_{2} \mathrm{O}_{2} & \mathrm{H}_{2} \mathrm{O}_{2}\end{array}$

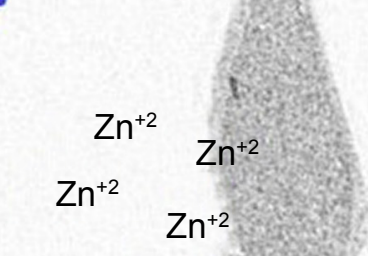

Figure 9 Effect of $0.1 \mathrm{M}, 0.05 \mathrm{M}$, and $0.01 \mathrm{M}$ synthesized $\mathrm{ZnO}$ NPs on the (A) viability of MDa-MB 23I cells, (B) viability of McF-7 cells, (C) proliferation of MDa-MB 23I cells, (D) proliferation of McF-7 cells. (E) Typical phase-contrast light-microscopy images obtained from tryphan blue exclusion assay of MDa-MB $23 \mathrm{I}$ and (F) McF-7 cell lines. Typical phase-contrast light-microscopy images (20x) of plasma membrane blebs (directed by an arrow) induced by synthesized ZnO NPs on (G) MDA-MB 23 I and (H) MCF-7 cell lines (I) Predicted mechanism behind cytotoxic activity of biosynthesized $\mathrm{ZnO} N P s$ using $A$. lebbeck stem bark against breast cancer lines. $* P<0.05$, $* * P<0.0 \mathrm{I}$, $* * * P<0.000 \mathrm{I}$. Abbreviation: ZnO NPs, zinc oxide nanoparticles.

shown in Figure 9E. Higher concentration of $100 \mu \mathrm{g} / \mathrm{mL}$ for $0.1 \mathrm{M}, 0.05 \mathrm{M}$, and $0.01 \mathrm{M} \mathrm{ZnO} \mathrm{NPs} \mathrm{decreased} \mathrm{MDA-MB}$ 231 viability to $53.6 \%, 60.1 \%$, and $66.2 \%$, respectively.
Synthesized ZnO NPs similarly revealed cytotoxic effects on the viability of MCF-7 cells in a concentration-dependent manner as shown in Figure 9B. The 0.1M ZnO NPs revealed 


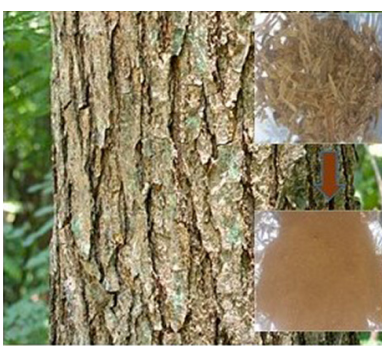

Albizia lebbeck stem bark

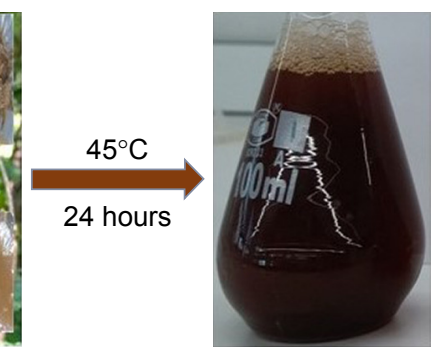

Extract

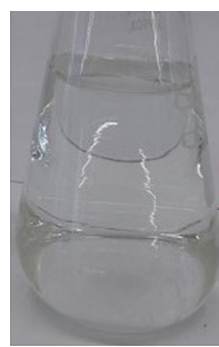

$\mathrm{Zn}\left(\mathrm{NO}_{3}\right)_{2} \cdot 6 \mathrm{H}_{2} \mathrm{O}$

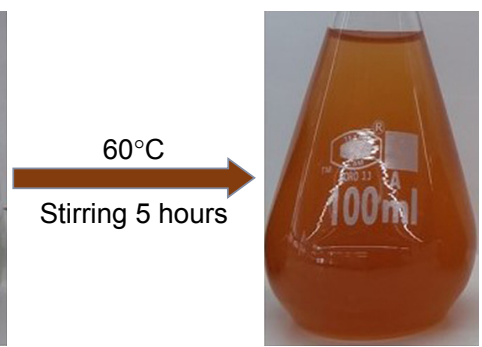

ZnO NPs

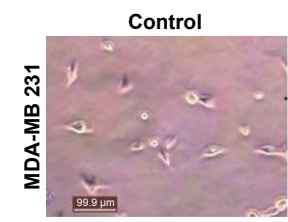

Control

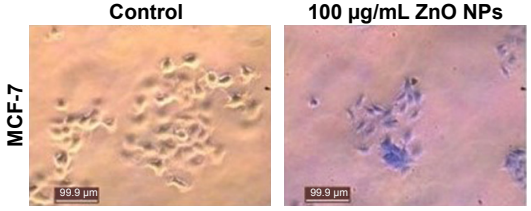

Anticancer and antibacterial activity
$100 \mu \mathrm{g} / \mathrm{mL} Z \mathrm{nO}$ NPs
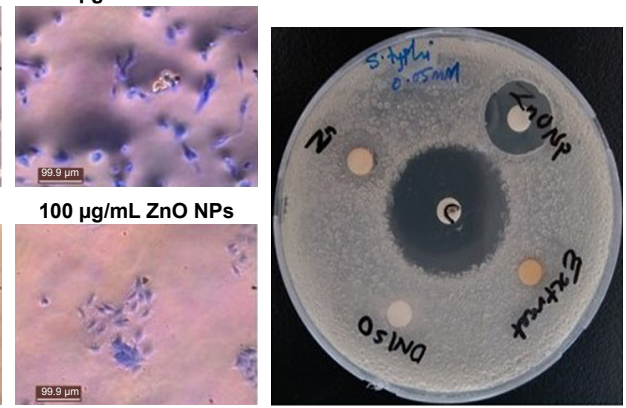

in higher cytotoxic effects than $0.05 \mathrm{M}$ and $0.01 \mathrm{M}$, which might be due to higher percentage of zinc in the nanoparticles. The $5 \mu \mathrm{g} / \mathrm{mL}$ dose of $0.05 \mathrm{M}$ and $0.01 \mathrm{M}$ synthesized $\mathrm{ZnO}$ NPs showed extremely significant difference when compared with control $(P<0.001, \mathrm{n} \geq 3$, Figure 9B), but a similar concentration of $0.1 \mathrm{M} \mathrm{ZnO} \mathrm{NPs} \mathrm{revealed} \mathrm{significant}$ difference upon comparison with the control $(P<0.001$, $\mathrm{n} \geq 3$, Figure 9A). Additionally, all the concentrations of $\mathrm{ZnO}$ NPs used in our study showed significant activity against MCF-7 cells when compared with control $(P<0.5, \mathrm{n} \geq 3$, Figure 9A and B). Typical phase-contrast light-microscopy images of ZnO NPs-treated MCF-7 cells and controls obtained from tryphan blue assays are shown in Figure 9F. $\mathrm{ZnO}$ NPs showed a cytotoxic effect against colon cancer cell lines HT29, and the effect was found to increase with increased particle concentration. ${ }^{46}$ Prashant et al reported the cytotoxic effect of $\mathrm{ZnO}$ nanopowders synthesized using Punica granatum and Tamarindus indica L. by combustionassisted facile process against MCF-7 Bca cell line; the cytotoxic effects were found to be concentration dependent, ${ }^{45}$ and the results were similar to those obtained in our studies.

The study also revealed effect on cell number as a confirmation of the cytotoxic effect of synthesized ZnO NPs on MDA-MB 231 and MCF-7 human Bca cell lines. Synthesized $\mathrm{ZnO}$ NPs of $0.1 \mathrm{M}, 0.05 \mathrm{M}$, and $0.01 \mathrm{M}$ showed a significant decrease in the proliferation of both cell lines when compared with control $(P<0.001, \mathrm{n} \geq 3$, Figure $9 \mathrm{C}$ and $\mathrm{D})$. The effects of the NPs on cell number following 24 hours incubation period were also found to be concentration dependent. High reduction in the cell number of both cell lines was observed with $0.1 \mathrm{M} \mathrm{ZnO} \mathrm{NPs} \mathrm{in} \mathrm{a} \mathrm{concentration-dependent} \mathrm{manner} \mathrm{and} 100$ $\mu \mathrm{g} / \mathrm{mL}$ inhibit the cell number of MDA-MB 231 and MCF-7 with $76.8 \%$ and $80.2 \%$, respectively; this finding served as a confirmation for the cytotoxic effect as determined by tryphan blue assay. Metal ion NPs and their peptide conjugates inhibit endothelial cell angiogenesis and proliferation through binding to endothelial growth factor, mitogens, and mediators of angiogenesis. ${ }^{32}$

Membrane blebs were also observed on MDA-MB 231 and MCF-7 cells treated with $\mathrm{ZnO}$ NPs synthesized using A. lebbeck stem bark, following 48 hours of incubation (Figure $9 \mathrm{G}$ and $\mathrm{H}$ ). This may possibly indicate an alternative apoptotic mechanism experienced by MDA-MB 231 and MCF-7 cells as membrane blebs were observed in the cells upon exposure to $\mathrm{ZnO}$ NPs (Figure 9I). It has been reported that plasma membrane blebs are among the basic sign that indicate apoptosis in cells. ${ }^{47}$ The plasma membrane blebs in our studies were also found to occur in a concentration-dependent manner as membrane blebs were not observed with the untreated cells (control) but were observed with treated cells in a concentration-dependent manner. Membrane blebbing and a decrease in cell viability observed in both cells might be a result of ROS, metal ions $\left(\mathrm{Zn}^{+2}\right)$, and other molecules released in the culture medium by the synthesized ZnO NPs. ${ }^{48}$ 
Hanley et al revealed that the increase in intracellular level of $\mathrm{Zn}^{+2}$ ions and other molecules released from $\mathrm{ZnO}$ NPs are correlated with an increase in ROS generation, and this will lead to apoptosis. ${ }^{49}$ The summary of the whole process involved can be seen in Figure 10.

\section{Conclusion}

Overall, various concentrations of $\mathrm{ZnO}$ NPs were synthesized through a stable, simple, and eco-friendly green route via the use of $A$. lebbeck stem bark extract. The extract acts as both reducing and stabilizing agent, which was confirmed by FTIR analysis. The successful synthesis of $0.1 \mathrm{M}, 0.05 \mathrm{M}$, and $0.01 \mathrm{M} \mathrm{ZnO} \mathrm{NPs} \mathrm{was} \mathrm{confirmed} \mathrm{by} \mathrm{Zeta} \mathrm{sizer,} \mathrm{UV-vis,}$ FTIR, XRD, SEM, and EDX analyses. The UV-vis spectroscopy revealed an absorption peak in the range of 370 $\mathrm{nm}$. SEM results revealed many agglomerated particles with irregular hexagonal morphology and an average size of $66.25 \mathrm{~nm}$. XRD spectrum revealed that the synthesized $\mathrm{ZnO}$ NPs have hexagonal wurzite structure. The biosynthesized $\mathrm{ZnO}$ NPs showed strong antimicrobial activity against $B$. cereus, $S$. aureus, E. coli, $K$. pneumoniae, and $S$. typhi. Various concentrations of the ZnO NPs demonstrated antioxidant activity. Additionally, the ZnO NPs showed significant cytotoxic effects and induction of membrane blebs on MDA-MB 231 and MCF-7 breast cancer cell lines in a concentration-dependent manner. The $0.1 \mathrm{M} \mathrm{ZnO} \mathrm{NPs}$ revealed the best biological activity compared with $0.05 \mathrm{M}$ and $0.01 \mathrm{M}$ nanoparticles and the whole process is illustrated in Figure 10.

\section{Acknowledgments}

The authors acknowledge the support of Prof. Dr. Mustapha Djamgoz, Department of Life Sciences, Faculty of Natural Sciences, Imperial College London.

\section{Disclosure}

The authors report no conflicts of interest in this work.

\section{References}

1. Albrecht MA, Evans CW, Raston CL. Green chemistry and the health implications of nanoparticles. Green Chem. 2006;8(5):417-432.

2. Xu D, Liu M, Zou H, et al. A new strategy for fabrication of water dispersible and biodegradable fluorescent organic nanoparticles with AIE and ESIPT characteristics and their utilization for bioimaging. Talanta. 2017;174:803-808.

3. Hassan HF, Mansour AM, Abo-Youssef AM, Elsadek BE, Messiha BA. Zinc oxide nanoparticles as a novel anticancer approach; in vitro and in vivo evidence. Clin Exp Pharmacol Physiol. 2017;44(2):235-243.

4. Nirmala M, Anukaliani A. Synthesis and characterization of undoped and TM (Co, Mn) doped ZnO nanoparticles. Mater Lett. 2011;65(17-18): 2645-2648.
5. Thapa A, Soares AC, Soares JC, et al. Carbon nanotube matrix for highly sensitive biosensors to detect pancreatic cancer biomarker CA19-9. ACS Appl Mater Interfaces. 2017;9(31):25878-25886.

6. El-Gharbawy RM, Emara AM, Abu-Risha SE. Zinc oxide nanoparticles and a standard antidiabetic drug restore the function and structure of beta cells in Type-2 diabetes. Biomed Pharmacother. 2016;84:810-820.

7. Rosi NL, Mirkin CA. Nanostructures in biodiagnostics. Chem Rev. 2005;105(4):1547-1562.

8. Jansen J, Karges W, Rink L. Zinc and diabetes - clinical links and molecular mechanisms. J Nutr Biochem. 2009;20(6):399-417.

9. Li H, Carter JD, Labean TH. Nanofabrication by DNA self-assembly. Mater Today. 2009;12(5):24-32.

10. Altıntaş YO, Unalan HE, Durucan C. Highly efficient room temperature synthesis of silver-doped zinc oxide ( $\mathrm{ZnO}: \mathrm{Ag}$ ) nanoparticles: structural, optical, and photocatalytic properties. J Am Ceram Soc. 2013;96(3): 766-773.

11. Chauhan R, Kumar A, Chaudhary RP. Structures and optical properties of $\mathrm{Zn}_{1-x} \mathrm{NiO}_{x}$ nanoparticles by co-precipitation method. Res Chem Intermid. 2012;38(7):1483-1493.

12. Vigneshwaran N, Kumar S, Kathe AA, Varadarajan PV, Prasad V. Functional finishing of cotton fabrics using zinc oxide-soluble starch nanocomposites. Nanotechnology. 2006;17(20):5087-5095.

13. Hameed ASH, Chandrasekaran K, Abdulazees PA. In vitro antibacterial activity of $\mathrm{ZnO}$ and $\mathrm{Nd}$ doped $\mathrm{ZnO}$ nanoparticles against $\mathrm{ESBL}$ producing Escherichia coli and Klebsiella pneumonia. Sci Rep. 2016;6:24312.

14. Brayner R, Ferrari-Illiou R, Brivois N, Djediat S, Benedetti MF, Fievet F. Toxicological impact studies based on Escherichia coli bacteria in ultrafine $\mathrm{ZnO}$ nanoparticles colloidal medium. Nano Lett. 2006;6(4): 866-870.

15. Adams LK, Lyon DY, Alvarez PJ. Comparative eco-toxicity of nanoscale $\mathrm{TiO}_{2}, \mathrm{SiO}_{2}$, and $\mathrm{ZnO}$ water suspensions. Water Res. 2006;40(19): 3527-3532.

16. Huang Z, Zheng X, Yan D, et al. Toxicological effect of $\mathrm{ZnO}$ nanoparticles based on bacteria. Langmuir. 2008;24(8):4140-4144.

17. Jones N, Ray B, Ranjit KT, Manna AC. Antibacterial activity of ZnO nanoparticle suspensions on a broad spectrum of microorganisms. FEMS Microbiol Lett. 2008;279(1):71-76.

18. Koleva II, van Beek TA, Linssen JP, de Groot A, Evstatieva LN. Screening of plant extracts for antioxidant activity: a comparative study on three testing methods. Phytochem Anal. 2002;13(1):8-17.

19. Balan K, Qing W, Wang Y, et al. Antidiabetic activity of silver nanoparticles from green synthesis using Lonicera japonica leaf extract. RSC Adv. 2016;6(46):40162-40168.

20. Suresh D, Nethravathi PC, Udayabhanu CG, Rajanaika H, Nagabhushana H, Sharma SC. Green synthesis of multifunctional zinc oxide $(\mathrm{ZnO})$ nanoparticles using Cassia fistula plant extract and their photodegradative, antioxidant and antibacterial activities. Mater Sci Semicond Process. 2015;31:446-454.

21. Zhang J, Qin X, Wang B, et al. Zinc oxide nanoparticles harness autophagy to induce cell death in lung epithelial cells. Cell Death Dis. 2017;8(7):e2954.

22. Wang D, Guo D, Bi H, Wu Q, Tian Q, Du Y. Zinc oxide nanoparticles inhibit Ca2+-ATPase expression in human lens epithelial cells under UVB irradiation. Toxicol In Vitro. 2013;27(8):2117-2126.

23. Suresh J, Pradheesh G, Alexramani V, Sundrarajan M, Hong SI. Green synthesis and characterization of zinc oxide nanoparticle using insulin plant (Costus pictus D. Don) and investigation of its antimicrobial as well as anticancer activities. Adv Nat Sci Nanosci Nanotechnol.2018;9(1):015008.

24. Sundrarajan M, Ambika S, Bharathi K. Plant-extract mediated synthesis of $\mathrm{ZnO}$ nanoparticles using Pongamia pinnata and their activity against pathogenic bacteria. Adv Powder Technol. 2015;26(5):1294-1299.

25. Ambika S, Sundrarajan M. Antibacterial behaviour of Vitex negundo extract assisted $\mathrm{ZnO}$ nanoparticles against pathogenic bacteria. J Photochem Photobiol B. 2015;146:52-57.

26. Padalia H, Moteriya $\mathrm{P}$, Chanda S. Synergistic antimicrobial and cytotoxic potential of zinc oxide nanoparticles synthesized using Cassia auriculata leaf extract. Bionanoscience. 2018;8(1):196-206. 
27. Lowry J. Trees for Wood and Animal Production in Northern Australia. Indooroopilly, Queensland: Rural Industries Research and Development Corporation; 2008:89.

28. Lam SK, Ng TB, Sze Kwan L, Tzi Bun N. First report of an anti-tumor, anti-fungal, anti-yeast and anti-bacterial hemolysin from Albizia lebbeck seeds. Phytomedicine. 2011;18(7):601-608.

29. Noté OP, Jihu D, Antheaume C, et al. Triterpenoid saponins from Albizia lebbeck (L.) Benth and their inhibitory effect on the survival of high grade human brain tumor cells. Carbohydr Res. 2015;404:26-33.

30. Zare E, Pourseyedi S, Khatami M, Darezereshki E. Simple biosynthesis of zinc oxide nanoparticles using nature's source, and it's in vitro bioactivity. J Mol Struct. 2017;1146:96-103.

31. Bauer AW, Kirby WM, Sherris JC, Turck M. Antibiotic susceptibility testing by a standardized single disk method. Am J Clin Pathol. 1966; 45(4):493-496.

32. Pick E, Mizel D. Rapid microassays for the measurement of superoxide and hydrogen peroxide production by macrophages in culture using an automatic enzyme immunoassay reader. J Immunol Methods. 1981; 46(2):211-226.

33. Fraser SP, Ding Y, Liu A, Foster CS, Djamgoz MB. Tetrodotoxin suppresses morphological enhancement of the metastatic MAT-LyLu rat prostate cancer cell line. Cell Tissue Res. 1999;295(3):505-512.

34. Fraser SP, Diss JK, Chioni AM, et al. Voltage-gated sodium channel expression and potentiation of human breast cancer metastasis. Clin Cancer Res. 2005;11(15):5381-5389.

35. Kokila T, Ramesh PS, Geetha D. Biosynthesis of AgNPs using Carica papaya peel extract and evaluation of its antioxidant and antimicrobial activities. Ecotoxicol Environ Saf. 2016;134(Pt 2):467-473.

36. Nagarajan S, Arumugam Kuppusamy K. Extracellular synthesis of zinc oxide nanoparticle using seaweeds of gulf of Mannar, India. J Nanobiotechnol. 2013;11:39.

37. Singh BN, Rawat AK, Khan W, Naqvi AH, Singh BR. Biosynthesis of stable antioxidant $\mathrm{ZnO}$ nanoparticles by Pseudomonas aeruginosa rhamnolipids. PLoS One. 2014;9(9):e106937.

38. Anilreddy B. Preparation and characterization of iron oxide nanoparticles on disaccharide templates. B JPRHC. 2009;1(2):172-183.

39. Kumar B, Smita K, Cumbal L, Debut A. Synthesis of silver nanoparticles using Sacha inchi (Plukenetia volubilis L.) leaf extracts. Saudi J Biol Sci. 2014;21(6):605-609.
40. Kadam A, Dhabbe R, Gophane A, Sathe T, Garadkar K. Template free synthesis of $\mathrm{ZnO} / \mathrm{Ag}_{2} \mathrm{O}$ nanocomposites as a highly efficient visible active photocatalyst for detoxification of methyl orange. $J$ Photochem Photobiol B. 2016;154:24-33.

41. Yuvakkumar R, Suresh J, Saravanakumar B, Joseph Nathanael A, Hong SI, Rajendran V. Rambutan peels promoted biomimetic synthesis of bioinspired zinc oxide nanochains for biomedical applications. Spectrochim Acta A Mol Biomol Spectrosc. 2015;137:250-258.

42. Raut S, Thorat PV, Thakare R. Green synthesis of zinc oxide ( $\mathrm{ZnO})$ nanoparticles using Ocimum tenuiflorum leaves. Int J Sci Res. 2013;4: $1225-1228$.

43. Sinha R, Karan R, Sinha A, Khare SK. Interaction and nanotoxic effect of $\mathrm{ZnO}$ and $\mathrm{Ag}$ nanoparticles against ESBL and Amp-C producing gram negative isolates from superficial wound infections. Int J Curr Microbiol Appl Sci. 2015;1:38-47.

44. Gough DR, Cotter TG. Hydrogen peroxide: a Jekyll and Hyde signalling molecule. Cell Death Dis. 2011;2:e213.

45. Parashant GK, Prashant PA, Utpal B, et al. In vitro antibacterial and cytotoxicity studies of $\mathrm{ZnO}$ nanopowders prepared by combustion assisted facile green synthesis. Karbala Int J Mod Sci. 2015;1(2):67-77.

46. Bai Aswathanarayan J, Rai Vittal R, Muddegowda U, Jamuna BA, Ravishankar AV, Umashankar M. Anticancer activity of metal nanoparticles and their peptide conjugates against human colon adenorectal carcinoma cells. Artif Cells Nanomed Biotechnol. 2018; 46(7):1444-1451.

47. Mukherjee $P$, Bhattacharya $R$, Wang $P$, et al. Antiangiogenic properties of gold nanoparticles. Clin Cancer Res. 2005;11(9):3530-3534.

48. Fackler OT, Grosse R. Cell motility through plasma membrane blebbing. $J$ Cell Biol. 2005;81:879-884.

49. Hanley C, Layne J, Punnoose A, et al. Preferential killing of cancer cells and activated human $\mathrm{T}$ cells using $\mathrm{ZnO}$ nanoparticles. Nanotechnology. 2008;19(29):295103.
International Journal of Nanomedicine

\section{Publish your work in this journal}

The International Journal of Nanomedicine is an international, peerreviewed journal focusing on the application of nanotechnology in diagnostics, therapeutics, and drug delivery systems throughout the biomedical field. This journal is indexed on PubMed Central, MedLine, CAS, SciSearch ${ }^{\circledR}$, Current Contents ${ }^{\circledR} /$ Clinical Medicine,

\section{Dovepress}

Journal Citation Reports/Science Edition, EMBase, Scopus and the Elsevier Bibliographic databases. The manuscript management system is completely online and includes a very quick and fair peer-review system, which is all easy to use. Visit http://www.dovepress.com/ testimonials.php to read real quotes from published authors. 